\title{
Do University Ecosystems Impact Student's Entrepreneurial Behavior?
}

\author{
Matheus Leite Campos ${ }^{1}$ \\ Gustavo Hermínio Salati Marcondes de Moraes ${ }^{2}$ \\ Ana Carolina Spatti ${ }^{1}$ \\ ${ }^{1}$ Universidade Estadual de Campinas, Campinas, SP, Brazil \\ ${ }^{2}$ Universidade Estadual de Campinas, Limeira, SP, Brazil
}

Received 30 July 2020. This paper was with the authors for two revisions. Accepted 18 May 2021.

First published online 31 May 2021.

Editors-in-chief: Carlo Gabriel Porto Bellini (D) (Universidade Federal da Paraíba, João Pessoa, PB, Brazil), Ivan Lapuente Garrido (D) (Universidade do Vale do Rio dos Sinos, Brazil)

Associate editor: Jorge Brantes Ferreira (ID (Pontifícia Universidade Católica do Rio de Janeiro, Brazil)

Reviewers: Two anonymous reviewers

Editorial assistants: Kler Godoy and Simone Rafael (ANPAD, Maringá, PR, Brazil) 


\section{ABSTRACT}

The goal of this study is to propose a conceptual model for assessing the impact of entrepreneurship supportive university ecosystems (ESUE) on student's entrepreneurship related behavioral characteristics: entrepreneurial intention (EI) and entrepreneurial characteristics (EC). The empirical research used partial least squares structural equation modeling (PLS-SEM) and a sample of 1,012 observations. Findings indicate that an ESUE has a positive influence on student's EI. However, this effect is mostly perceived on the changing of student's EC than on the direct stimulation for becoming entrepreneurs. Moreover, student's EI is also influenced by the greater entrepreneurial ecosystem in which universities are embedded. Evidences hint at the possibility that the university's push for entrepreneurship is insufficient. University and/or public managers stand to benefit from our findings for reassessing their current arrangements for fostering student entrepreneurship and designing new, more efficient mechanisms. Moreover, the literature presents a myriad of localized assessments of small countries, whereas this research provides a rough nation-wide overview of a continent-sized nation, thus contributing to the testing of the model against different contexts.

Keywords: entrepreneurship; entrepreneurial ecosystem; entrepreneurial characteristics

JEL Code: M130 


\section{INTRODUCTION}

Entrepreneurship is seen by many as a cornerstone for development (Chiru, Tachiciu, \& Ciuchete, 2012; Davey, Rossano, \& van der Sijde, 2016; Robinson \& Shumar, 2014) and the solution for many contemporary socioeconomic problems (see Bruton, Ketchen, \& Ireland, 2013; Sutter, Bruton, \& Chen, 2019). In this regard, entrepreneurial ecosystems have become the "holy grail" (Isemberg, 2010, p. 3) for governments to promote in-country, knowledgeintensive entrepreneurship and reap all its associated benefits (especially economic growth). However, there is no magic formula for how to properly set up this kind of ecosystem, and within the academia there is still a need for more consistent theoretical foundation and empirical evidence on the matter (Wurth, Stam, \& Spigel, 2021). On the other hand, it is possible to identify the underlining structure and core components of an entrepreneurial ecosystem, among which we find universities (Isemberg, 2010).

The university is recognized as a fundamental agent for the development of entrepreneurship (Muscio \& Ramaciotti, 2019; Saeed, Yousafzai, Yani-De-Soriano, \& Muffatto, 2015; Turker \& Selcuk, 2009). So much so that in the past few decades, be it by increased funding pressures, or by the general sign of the entrepreneurial times universities find themselves in (Freel, Persaud, \& Chamberlin, 2019), their two primary roles, of teaching and researching, have given up space for a third one to emerge: to serve as a hub for innovation and business making (Duruflé, Hellmann, \& Wilson, 2018). In this respect, several studies were conducted in order to better understand this phenomenon, specifically about how it is that the university ecosystem (UE) affects the entrepreneurial intention (EI) of students (Al-Shammari \& Waleed, 2018; Barbosa, Gerhardt, \& Kickul, 2007; Barral, Ribeiro, \& Canever, 2018; Kristiansen, 2004; Liñán, 2004; Maresch, Harms, Kailer, \& Wimmer-Wurm, 2016; Ngoc Khuong \& Huu An, 2015; Saeed et al., 2015; Shirokova, Osiyevskyy, \& Bogatyreva, 2016; Tiago, Faria, Couto, \& Tiago, 2015; Vodă \& Florea, 2019).

The dynamics of each UE shapes the way in which its community produces entrepreneurial results. However, the extent of the university's mechanisms for fostering entrepreneurship among the student community is still a matter of investigation (Ahmed, Chandran, \& Klobas, 2017; Alves, Fischer, Schaeffer, \& Queiroz, 2019; Moraes, Iizuka, \& Pedro, 2018; Muscio \& Ramaciotti, 2019), with no consensus as to what policy or resource is most effective to this end (Fischer, Moraes, \& Schaeffer, 2019; Moraes, Fischer, Campos, \& Schaeffer, 2020). This gap seems to be wider in the context of developing countries, which usually tend to emulate practices from more advanced economies without much adaptation to their particularities (Alves et al., 2019; Fischer et al., 2019; Moraes et al., 2018).

Based on these arguments, we identify the need for further investigations on the effectiveness of university level entrepreneurship mechanisms (Alves et al., 2019; Fischer et al., 2019; Moraes et al., 2018). Therefore, our goal is to propose a conceptual model for assessing the impact of entrepreneurship supportive university ecosystems on student's entrepreneurship related behavioral characteristics: entrepreneurial intention and entrepreneurial characteristics. For that 
end, we empirically tested the model with a countrywide survey of Brazilian Business Administration students. Our model is largely based on the framework proposed by Saeed et al. (2015); however, its originality comes from testing the direct effect of UE and EC on student's EI, thus revealing if their willingness to develop entrepreneurial activities is context on intrinsically driven. Furthermore, by developing a comprehensive model we aim to make a theoretical and practical contribution to the better understanding of the UE's influence on student's EI and their subsequent intention to choose entrepreneurship as a career option.

There are over 290 higher education institutions in Brazil (Instituto Nacional de Estudos e Pesquisas Educacionais Anísio Teixeira [INEP], 2018), with 43.7\% concentrated on the southeastern region alone (Instituto Nacional de Estudos e Pesquisas Educacionais Anísio Teixeira [INEP], 2019). The country's population is estimated around $210 \mathrm{mi}$ people, with a GDP per capita of approximately $\mathrm{R} \$ 30$ thousand (Instituto Brasileiro de Geografia e Estatística [IBGE], 2019). Business Administration is one of the curricula with the highest number of enrolments: more than $1.2 \mathrm{mi}$ students (INEP, 2018). Moreover, Brazil's overall population presents a moderate to high entrepreneurship intention level (Global Entrepreneurship Monitor [GEM], 2019). Therefore, the Brazilian background provides many opportunities for testing the model and evaluating the university ecosystem's impact on student's entrepreneurship related behavior.

From a higher education standpoint, Brazilian universities are divided between public (mostly federal or state managed) and private institutions. The Southeast concentrates $43.7 \%$ of the country's universities, leaving $16.3 \%$ for the Southern region, $21.6 \%$ for the Northeastern, and the remaining $18.4 \%$ for the Midwest and North. From the total number of higher education institutions (HEIs), there are more private institutions (89\%) than public ones (11\%). Furthermore, data from 2017 shows that there are more than 4,500 Business Administration (BA) courses in Brazil (INEP 2019).

On section 2, we present a theoretical discussion about the university ecosystem, entrepreneurial intention, and entrepreneurial characteristics. At the same time, we put forth the theoretical basis of our hypotheses and the antecedents of our model. On section 3, we present the theoretical model as well as the tools and methods employed during the research. Section 4 , by its turn, is dedicated to the results obtained with the empirical testing of our model. Finally, sections 5 and 6 , respectively, present the discussion of our findings and our conclusions.

\section{THEORETICAL DISCUSSION}

A common, though incomplete understanding about entrepreneurship is that it is all about opening a new business (Robinson \& Shumar, 2014). In itself, entrepreneurship is an activity that greatly affects society and the production of wealth. However, only successful cases are able to do so (Maroufkhani, Wagner, \& Wan Ismail, 2018). And, in order to be successful, a firm must not rely solely on its strategy and capabilities, but also on the sharing of resources, network externalities, and governmental support, among other factors (Audretsch, Cunningham,

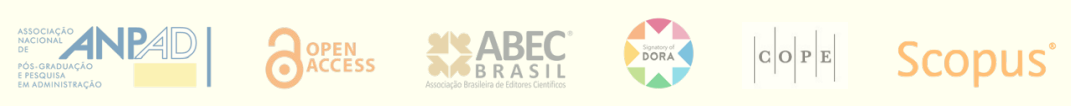


Kuratko, Lehmann, \& Menter, 2019). Thus, entrepreneurs benefit from elements that go beyond the firm and form what is called an entrepreneurial ecosystem (EEc).

Literature does not provide a single, unified definition for EEcs (Brown \& Mason, 2017; Tsujimoto, Kajikawa, Tomita, \& Matsumoto, 2018). The origins of this concept can be traced back to Moore (1993), who compared the evolutionary dynamics of firms to the natural environment. Isemberg (2010) describes it as a set of individual elements combined in complex forms. Qian, Acs, and Stough (2013) defined it as a non-linear conjunction of factors that "interactively influence the creation, discovery and exploitation of entrepreneurial opportunities" (Qian, Acs, \& Stough, 2013, p. 561). Mason and Brown (2014), by their turn, add the notion of (in)formality and describe it as an interconnected set of actors, organizations, and processes that "coalesce to connect, mediate and govern the performance within the local entrepreneurial environment" (Mason \& Brown, 2014, p. 5). This notion is further complemented by Stam and Spigel (2016, p. 1), who constrain the EEc to a geographical clustering of well-connected factors with the power of nurturing business ventures. Regardless of the adopted definition, literature converges on the notion that an EEc is composed of several pieces that coalesce to produce dynamic synergies. Figure 1 presents an EEc framework that summarizes these concepts.

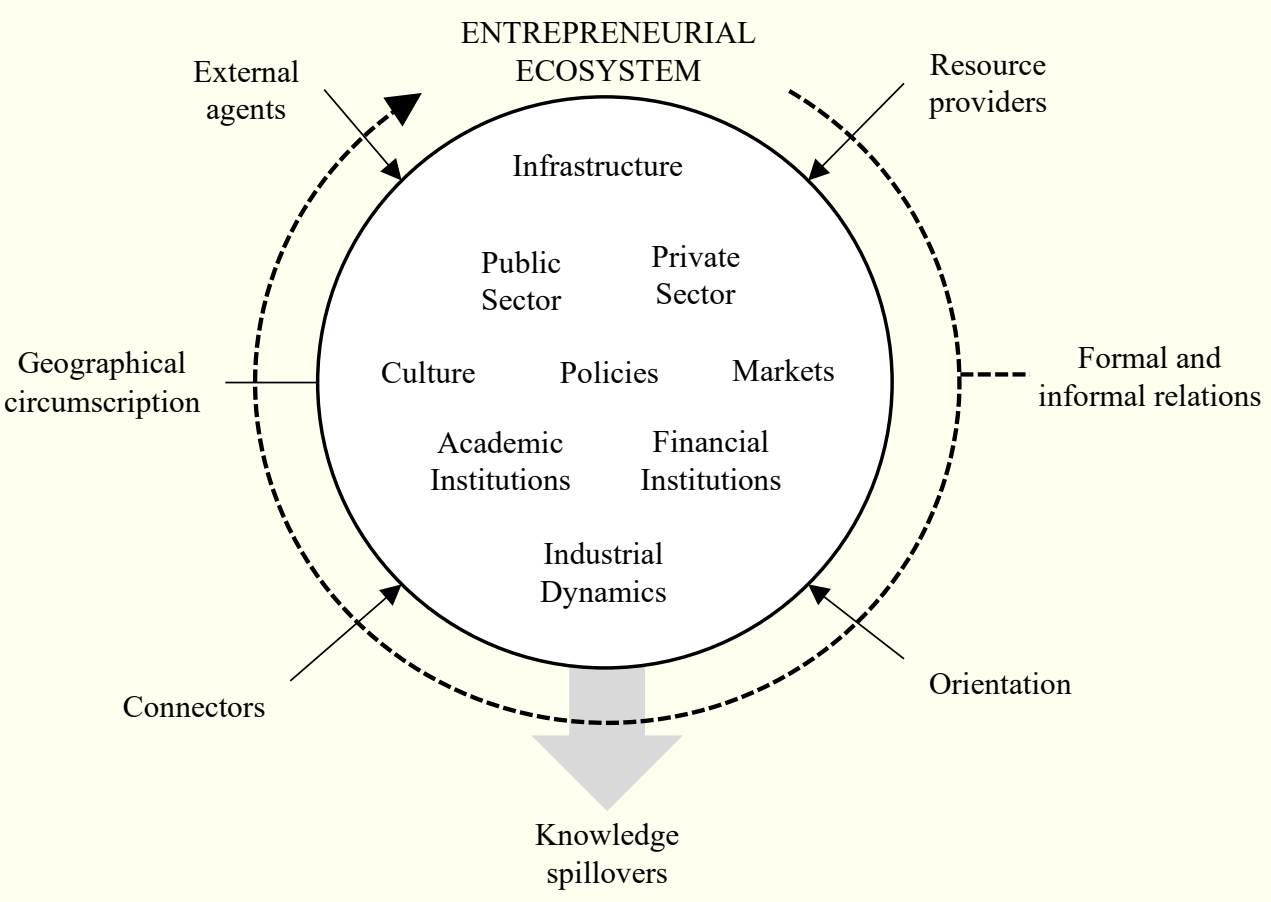

Figure 1. Graphical representation of an entrepreneurial ecosystem and its key actors.

Within this framework, we find universities (academic institutions). Given their importance to the development of EEcs worldwide (World Economic Forum et al., 2013), it is imperative to stress that its environment (Moraes et al., 2018) and faculty can exert great influence on student's willingness to actively engage on entrepreneurial activities (Neumeyer, Santos, \& Morris, 2019). 
One very important aspect of the Brazilian higher education scenario is that public universities, as opposed to private universities, respond for the majority of research activities (Alves, Quelhas, Silva, \& Lameira, 2015). Therefore, they are primary sources of new, innovative knowledge and are important links for connecting actors across the entrepreneurial ecosystem, especially in the local context. Moreover, public universities are constantly developing their peripheral capabilities (Clark, 2003) in order to better connect with other actors within the EC. This lead to the establishment of Technology Transfer Offices (TTOs) dedicated to the management of knowledge spillovers and the establishment of partnerships with the industry. However, it is important to stress the economic impact of this information.

To illustrate, if we look at the case of Unicamp, one of Brazil's biggest public universities in terms of students, funding, and research activity, the presence of a TTO and business incubators and accelerators led to the establishment of 701 spin-off companies with a turnover of $\mathrm{R} \$ 4.8 \mathrm{bi}$ (INOVA, 2018). This data highlights the important part public universities play in the production of knowledge and the potential they represent for the establishment of innovative business ventures. Incubators, especially, form an environment that allows students to get handson experience on running a business, thus developing technical skills, product and market knowledge, and understanding of organizational structures (Mason, \& Brown, 2014). On the next sections, we provide a theoretical overview of entrepreneurial intention, university ecosystem, and entrepreneurial characteristics, which lay the foundation for our hypotheses.

\section{Entrepreneurial intention}

Intention is a predictor to conscious behavior (Al-Jubari, Hassan, \& Liñán, 2018). Krueger, Reilly, and Carsrud (2000) take it one step further and claim to be "the single best predictor of any planned behavior" (Krueger, Reilly, \& Carsrud, 2000, p. 412). Therefore, intention serves as bridge between ideas and actions (Saeed-et al., 2015). EI, by its turn, is the conscious decision of wanting to engage on a self-owned business venture and planning to do so in the future (Thompson, 2009), even long before an opportunity has been realized. In the specific case of universities, it is as prerequisite for any graduate or undergraduate student to start their own business (Karim, 2016).

Intention in general depends on situational and personal characteristics (Krueger et al., 2000). Therefore, EI is a function of the university's educational, relational, and structural supports as well as of personality traits and one's own characteristics (Turker \& Selcuk, 2009). Several studies highlight the positive influence that the university ecosystem exerts on student's entrepreneurial behavior (Abualbasal \& Badran, 2019; Ferrandiz, Fidel, \& Conchado, 2018; Kuratko \& Morris, 2018; Mustafa, Hernandez, Mahon, \& Chee, 2016), in the sense that a positive environmental influence empowers students to take action and start their businesses, thus becoming full-fledged entrepreneurs (Trivedi, 2016).

Empirical evidence attesting to this effect can be found in the literature. Souitaris, Zerbinati, and Al-Laham (2007) tested what they deemed conventional wisdom: that entrepreneurship programs in universities tend to increase the intention of starting a business. By means of a pretest-post-

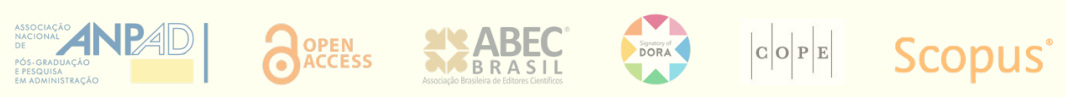


test quasi-experimental design with 250 students, they were able to confirm not only the intention-behavior link but also the effect of exogenous influence (education) on intention as well (similar results can be found in Peterman \& Kennedy, 2003). Muscio and Ramaciotti (2019) sampled over 9,000 Ph.D. students and found that both university and course-level factors are key to mobilizing students toward entrepreneurship. Tiago, Faria, Couto, and Tiago (2015) found that even between countries education in entrepreneurship can be a main contributor to EI. Von Graevenitz, Harhoff, \& Weber (2010) have found that entrepreneurial education serves as an update for students own beliefs in their capability of acting as business owners, therefore reinforcing their intention to become entrepreneurs.

\section{University ecosystem}

The literature presents the term 'anchor tenants' to refer to key actors within an EEc that stimulate active growth and innovation, a role often fulfilled by universities (Colombelli, Paolucci, \& Ughetto, 2019). This is partially explained by their capacity to generate insights for future research problems (Audretsch \& Link, 2017) and the part they play on the creation of high-tech ventures, often the determinant factor for the technological development of a given geographical area (Ghio, Guerini, \& Rossi-Lamastra, 2019).

On the specific case of the Brazilian higher education context, empirical evidence attests to the importance major universities - particularly federal or state-managed, which are responsible for the bulk of research production (as mentioned in the introduction of section 2) - play in structuring successful ecosystems (Schaeffer, Fischer, \& Queiroz, 2018), thus supporting the notion of acting as anchor tenants. The Brasil Júnior's (2019) ranking of entrepreneurial universities illustrates this situation: from the 123 ranked institutions, only 6 (4\%) HEIs were private, thus revealing how much public institutions contribute to the country's entrepreneurial scene.

"Ecosystems can vary by technology, network intensity and organizational variety" (Hayter, Nelson, Zayed, \& O'Connor, 2018, p. 1040). We must keep in mind that every university will produce entrepreneurial activity according to its own resources and capacities (Hayter et al., 2018). Faculty (see Moraes et al., 2020), staff, departments, TTOs, etc. are all unique to each institution and contribute to the creation of an identity for the university, which will deeply affect its reputation among researchers, companies, and the general public. Furthermore, the policies governing both the internal environment of institutions and the higher education system as a whole will also affect the way entrepreneurial activity is produced. Moreover, it is important to stress that universities are not closed systems. Their interaction with organizations outside of their walls is another important factor for producing commercially exploitable opportunities, which will also shape the way they deal with business ventures (Rothaermel, Agung, \& Jiang, 2007). The combination of resources, along with the connection with other actors and their resources, is what constitutes an ecosystem centered on the university.

With this in mind, differences between countries and regions are to be expected. Brazilian policies, regarding the overall entrepreneurial activities of universities, is somewhat similar to

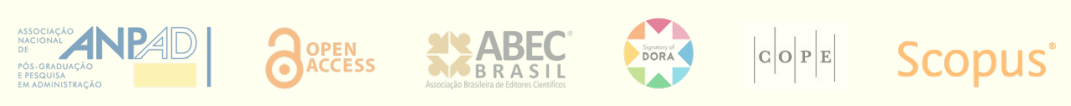


those found in the leading economies (especially the USA and Europe) (Dalmarco, Hulsink, \& Blois, 2018). However, there is a historic disconnection between the country's industrial evolution and the development of universities. Thus, the effects on research and development partnerships and knowledge transfer can be felt within the entrepreneurial ecosystem. Although public universities are responsible for the majority of knowledge production and engage with industries for collaboration, this happens at a much lower rate than in developed economies (Amadei \& Torkomian, 2009; Dalmarco et al., 2018), which calls for a better understanding of the particularities of this process.

The definition of UE used in this paper follows along the lines of Miller and Acs (2017), Morris, Shirokova, and Tsukanova, 2017), Rideout and Gray (2013), and Rothaermel, Agung, and Jiang (2007): it is an arrangement of elements, pertaining to the sphere of universities and the higher education system in general, which interact with each other and the external environment to produce entrepreneurial activity. In this sense, our definition of UE is very close to that of an EEc: a conjunction of actors and factors (as designated by Isemberg, 2010). The main difference is that the interacting elements, instead of being general in nature, are exclusive to the scope of universities.

Regarding the manner in which the UE stimulates the entrepreneurship related behavior of students, four specific dimensions must be taken into consideration: perceived educational support (PES); perceived concept development support (PCD); perceived business development support (PBD), which combine to form a dimension named by Saeed et al. (2015) as perceived university support; and perceived entrepreneurial characteristic development support (ECD) (Mustafa, Hernandez, Mahon, \& Chee, 2016). This support structure is graphically explained on Figure 2.

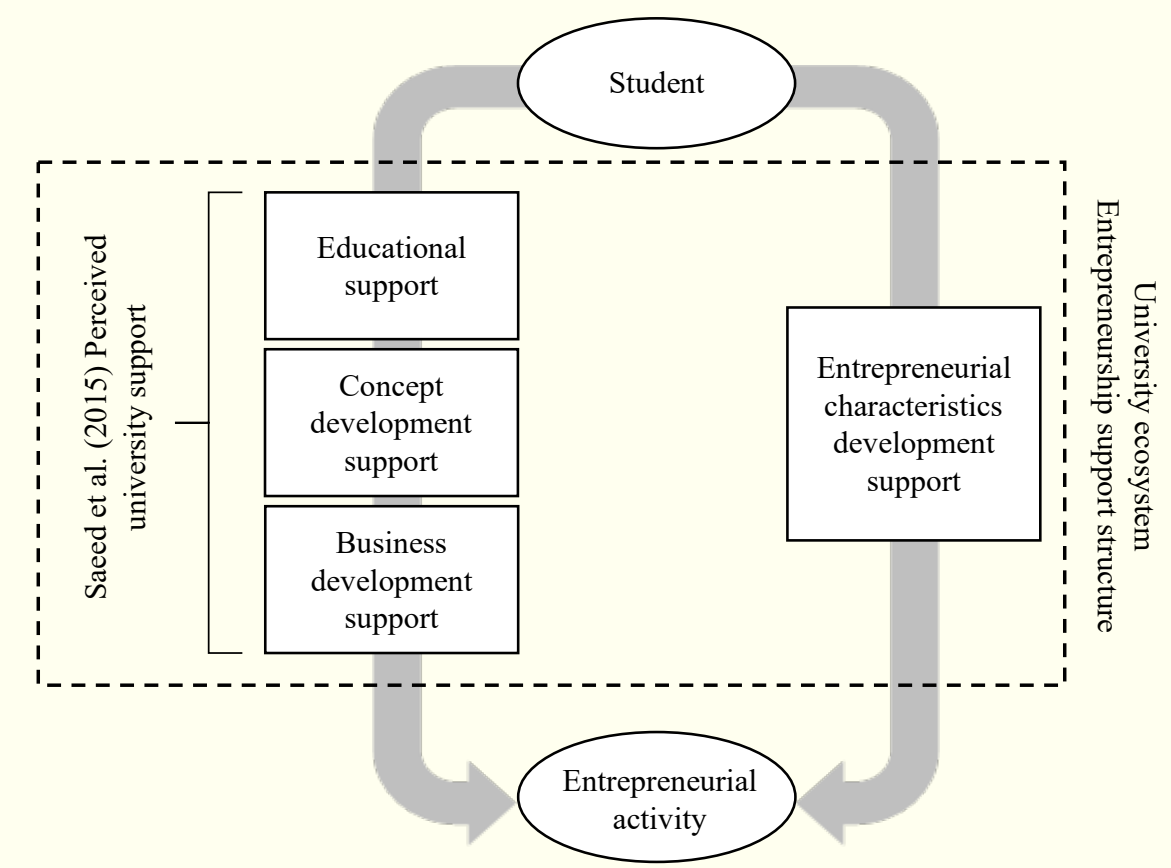

Figure 2. Entrepreneurship supportive university ecosystem.

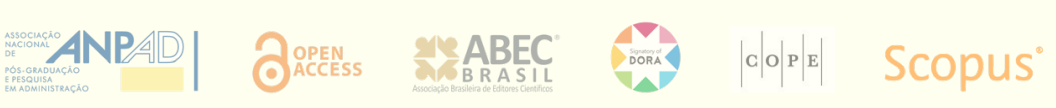


Educational support is focused on the traditional role of the university of conveying knowledge and skills to students and providing them with the necessary information for starting an entrepreneurial career (Mustafa et al., 2016; Saeed et al., 2015). This concept materializes in many forms, spanning from traditional theoretically-based classes to workshops and several other kinds of active interventions dedicated to teaching students entrepreneurship related knowledge. Empirical studies show that different forms of educational support lead to different results in terms of stimulating student's self-assessed characteristics and aptitudes, such as skills, knowledge, and self-efficacy (Vodă \& Florea, 2019). Nonetheless, this seems to be more associated to theoretically oriented interventions than practical courses, which, in turn, have a stronger tendency to affect student's willingness to become entrepreneurs (see Piperopoulos \& Dimov, 2015).

Concept development support, on the other hand, has to do with the transformation of entrepreneurial knowledge into viable business options (Mustafa et al., 2016; Saeed et al., 2015; Shane \& Venkataraman, 2000). In other words, it has to do with the conceptualization of a business model. Therefore, workshops, networking with role models from the business world, entrepreneurship related events, and other initiatives such as these can assist students in drawing business options for themselves and think of its implications, connection, material and immaterial flows, etc. Business development support, by its turn, takes the business concept one step further. It is related to the university developing financial arrangements for students and supporting businesses from day one (Saeed et al., 2015). It is at this stage that the elements of a UE, such as business incubators (Trivedi, 2016) and funding, will pool together to form actual businesses and, in many cases, direct academic spin-offs.

Lastly, the fourth dimension of UE support is entrepreneurial characteristics development support. According to the literature, the last three dimensions, with special emphasis on education, will not only provide students with insights into the entrepreneurial routine, but also promote a shift in mentality, which will ultimately affect their subsequent behavior (Mustafa et al., 2016). Therefore, entrepreneurial characteristics are developed parallel to the other support structures (Figure 2). As students enroll into subjects, participate on workshops, and develop their own business concepts, they are susceptible to also develop an entrepreneurial mindset.

By concentrating on these four dimensions, we take a more analytical approach to the effect of the university on supporting entrepreneurship related behavioral characteristics, thus linking the UE to the way students develop their own entrepreneurial self. Hence, our first hypothesis is as follows:

H1: An entrepreneurship supportive university ecosystem has a positive influence on undergraduate student's entrepreneurial intention.

\section{Entrepreneurial characteristics}

EC can be defined as a conjunction of personal traits (intrinsic elements) that affect one's behavior and are in line with the entrepreneurial mindset, significantly influencing an 
individual's intention to engage in entrepreneurial activity (Ajzen, 1991; Saeed et al., 2015). A set of eight such traits is commonly associated to entrepreneurs: self-efficacy, risk-taking, planning, opportunity recognition, persistency, sociability, innovation, and leadership (Moraes et al., 2018).

It is not enough for a person to know the 'tools of the trade' (entrepreneurship theory). One must develop an entrepreneurial mindset in order to become a successful entrepreneur (Morris, Kuratko, \& Cornwall, 2013). In this respect, the university "provides an excellent environment for individuals to develop the capabilities others are born with" (Gieure, Benavides-Espinosa, \& Roig-Dobón, 2019, p. 1614). In other words, the university's educational support mechanisms have the double task of teaching entrepreneurship related tools and skills and of providing students with the correct framework from which to build their behavior upon (Kuratko \& Morris, 2018).

Empirical evidence abounds on the positive effects that the university's educational support structures play in teaching skills and inspiring the correct entrepreneurial mindset on students (Abualbasal \& Badran, 2019; Ferrandiz et al., 2018; Ratang, Blesia, Goldstein, Ick, \& Hutajulu, 2016; Rideout \& Gray, 2013). For example, Morris, Webb, Fu, and Singhal (2013) have shown that different scripts for teaching entrepreneurship lead to the development of different competencies in students. Lucas and Cooper (2004), who tested the impact of a one-week entrepreneurship event at the Cambridge-MIT Institute, discovered that the proposed structured intervention had an enhancing effect on student's self-efficacy. Detienne and Chandler (2004), by their turn, concluded that individuals can learn processes of opportunity identification by means of specific training. Lastly, Thursby, Fuller, and Thursby (2009) found that students who undertook a given technology entrepreneurship program were much more aware of their entrepreneurial capabilities, thus seeing themselves as more capable of performing on technologyintensive environments. These examples illustrate that the manner by which students are lead to understand entrepreneurship affects their intention and behavior toward it (Testa \& Frascheri, 2015). Thus, the form of delivering educational support mechanisms significantly affect the way entrepreneurship-related knowledge is assimilated and, ultimately, influences student's EI (Shahab, Chengang, Arbizu, \& Haider, 2019).

Therefore, in face of the important role the university plays in building student's entrepreneurial mindset and characteristics, our second hypothesis is as follows:

H2: An entrepreneurship supportive university ecosystem has a positive influence on undergraduate student's entrepreneurial characteristics.

Furthermore, there are evidences in the literature regarding a direct and positive relation between individual entrepreneurial characteristics and EI. For example, Zhao, Chengang, Arbizu, and Haider (2005) have found that self-efficacy is strongly related to intention, which is consistent with other examples from other researches (Boyd \& Vozikis, 1994; Liguori, Bendickson, \& McDowell, 2018; Rosique-Blasco, Madrid-Guijarro, \& García-Pérez-de-Lema, 2018). On the same note, Lüthje and Franke (2003) have found that risk-taking propensity and internal locus of control are indirectly linked to EI, for these are component factors of attitudes toward

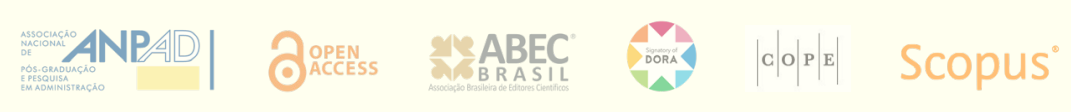


entrepreneurship. Mustafa, Hernandez, Mahon, and Chee (2016), by their turn, found that a proactive personality is positively related to entrepreneurial intention beyond the effects of the environment. Therefore, our third hypothesis represents the direct relation between EC and EI and reads as follows.

H3: Entrepreneurial characteristics have a positive influence on undergraduate student's entrepreneurial intention.

\section{RESEARCH METHODOLOGY}

For this empirical research, we opted for using partial least squares structural equation modeling (PLS-SEM) in order to identify degrees of prediction and explanation of presented constructs (as recommended by Hair, Hult, Ringle, \& Sarstedt, 2017). In order to estimate sample size and evaluate the statistical power of analyses, we used the $G^{*}$ Power 3.1 software (Faul, Erdfelder, Buchner, \& Lang, 2009), as per recommendations by Chin and Newsted (1999), Cohen (1988), and Hair, Hult, Ringle, and Sarstedt (2017). Since the largest number of predictors (arrows that reach a latent variable) is eight, according to the conceptual model, in order to reach statistical power of 0.8 , significance level of $5 \%$, and average effect size $\left(f^{2}\right)$ of 0.15 (equivalent to $\mathrm{R}^{2}=13 \%$ ), minimum sample size required is 109 valid observations; a threshold that was kept for each macro-region. The sample aspect is presented in Table 1.

\section{Table 1}

Sample aspect

\begin{tabular}{|c|c|c|c|c|c|c|}
\hline Macro-region & Name of the higher education institution & Acronym & $\begin{array}{l}\text { EUR } \\
\text { rank* }^{*}\end{array}$ & $\begin{array}{c}\text { Total valid } \\
\text { samples }\end{array}$ & \multicolumn{2}{|c|}{$\%$} \\
\hline $\mathrm{N}$ & Universidade do Estado do Amazonas & UEA & $54^{\text {th }} / 3^{\text {rd }}$ & 144 & $14.2 \%$ & $14.2 \%$ \\
\hline NE & Universidade Federal de Campina Grande & UFCG & $95^{\text {th }} / 27^{\text {th }}$ & 222 & $21.9 \%$ & $21.9 \%$ \\
\hline MW & Universidade de Brasilia & UNB & $8^{\mathrm{th} / 1^{\mathrm{st}}}$ & 194 & $19.2 \%$ & $19.2 \%$ \\
\hline \multirow{2}{*}{ SE } & Universidade Estadual de Campinas & UNICAMP & $2^{\text {nd }} / 2^{\text {nd }}$ & 191 & $18.9 \%$ & \multirow{2}{*}{$27.3 \%$} \\
\hline & Universidade de São Paulo & USP & $1^{\text {st }} / 1^{\text {st }}$ & 85 & $8.4 \%$ & \\
\hline \multirow{2}{*}{ s } & Universidade Tecnológica Federal do Paraná & UTFPR & $30^{\text {th }} / 13^{\text {th }}$ & 96 & $9.5 \%$ & \multirow{2}{*}{17.4} \\
\hline & Universidade Federal do Rio Grande do Sul & UFRGS & $4^{\text {th }} / 1^{\text {st }}$ & 80 & $7.9 \%$ & \\
\hline & & & TOTAI & $1,012^{* *}$ & $100 \%$ & $100 \%$ \\
\hline
\end{tabular}

Note. * Brasil Júnior's Entrepreneurship University Ranking 2019. First number refers to the university's overall position. Second number refers to the university's position within its macro-region. ${ }^{*} 22$ years old, in average; $51.6 \%$ male and $48.4 \%$ female; $92.8 \%$ single, $4.8 \%$ married and $2.4 \%$ other declared civil status.

In respect to data gathering, a single cross-section survey was conducted between August and October of 2019. Given the number and variety of HEIs in Brazil, the criteria for defining our population were based on two points. First, we focused our attention toward public universities of federal or state management to avoid analyzing public and private contexts together, which could result in unwanted variations. Second, we used the Entrepreneurial Universities Ranking

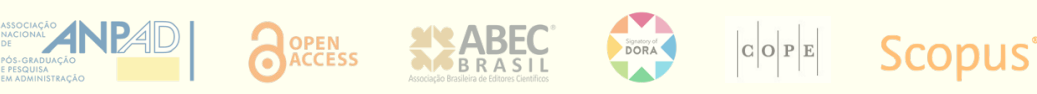


(EUR) as a guide. The EUR is a national ranking that takes into account three distinct dimensions for measuring the entrepreneurial profile of a university: (1) favorable ecosystem (infrastructure, internationalization activities, and financial capital), (2) academic community (entrepreneurial culture), and (3) society (innovation and other services and activities provided both to the local community and society in general) (Brasil Júnior, 2019).

After defining our population, we contacted the heads of the Business Administration departments of the highest-ranking universities and solicited their cooperation for applying our survey to their students. The support we received from the universities granted that we were able to sample all macro-regions without having to resort to online questionnaires, which have a tendency to present lower response rates (Lefever, Dal, \& Matthíasdóttir, 2007). Students were surveyed in person during class breaks and the completed questionnaire forms were mailed to the researchers for compilation. After receiving all forms, a post hoc analysis indicated an average effect size power of 0.999 - well above the initial 0.8 threshold recommended by Hair et al. (2017) and Chin and Newsted (1999) - and that any $\mathrm{R}^{2}$ value higher than $3.52 \%$ would be significant (thus keeping the statistical power of 0.8 and the significance level of $5 \%$ ).

On the following sections, we will explain the two-stage approach used in the hierarchical constructs and present the conceptual model.

\section{Conceptual model}

Building of the conceptual model involved a two-stage approach. On the first stage, all four types of university support (PES, PCD, PBD, and ECD) individually related to EI (H1), as well as to all eight entrepreneurial characteristics $(\mathrm{H} 2)$. These characteristics, by their turn, were also individually related to EI (H3), as demonstrated by Figure 3.

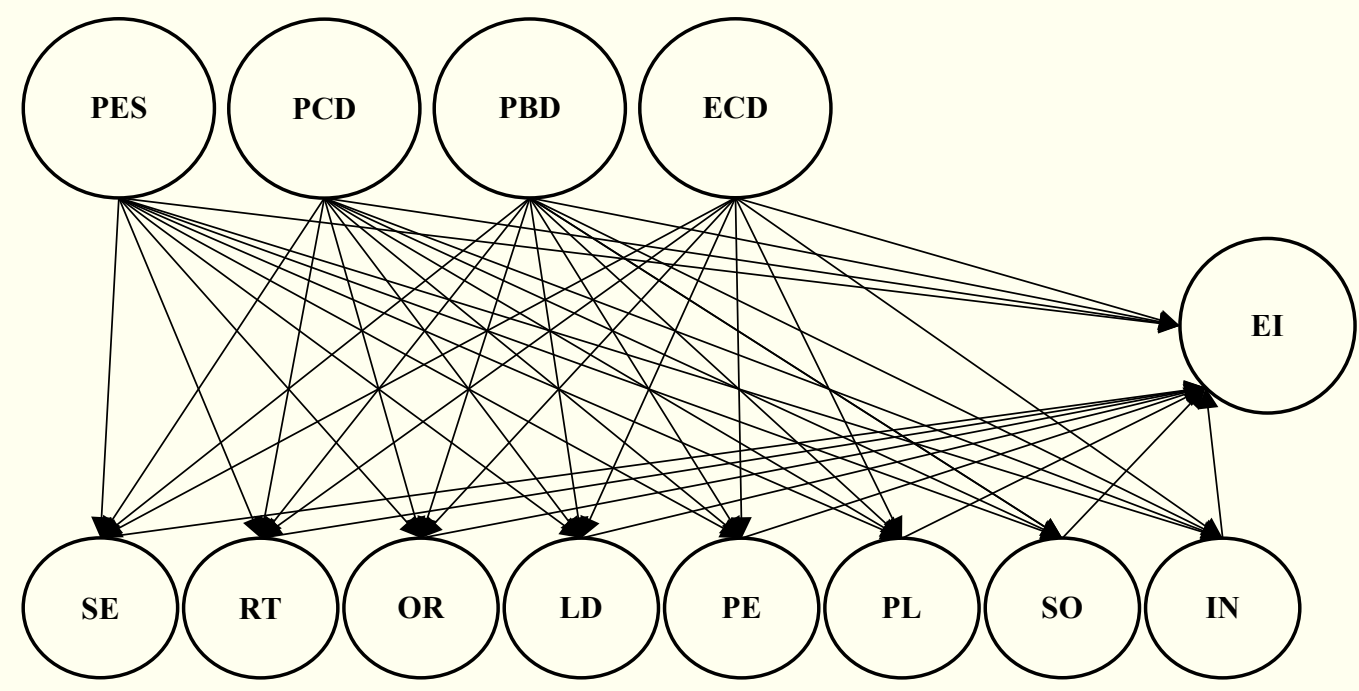

Figure 3. First stage model in the two-stage approach. 
On the second-stage model, the UE and EC constructs are added as hierarchical latent variables. UE comprises all four support types of university support while EC represents all eight entrepreneurial characteristics, which means they are both considered to be high order constructs (HOCs) formed by low order constructs (LOCs) (Hair, Sarstedt, Ringle, and Gudergan 2018), as demonstrated by Figure 4. In this case, relations between the HOCs and the LOCs do not portray dependence, but hierarchy (Becker, Klein, and Wetzels 2012; Sarstedt et al., 2019), since the HOC does not exist without the LOCs.

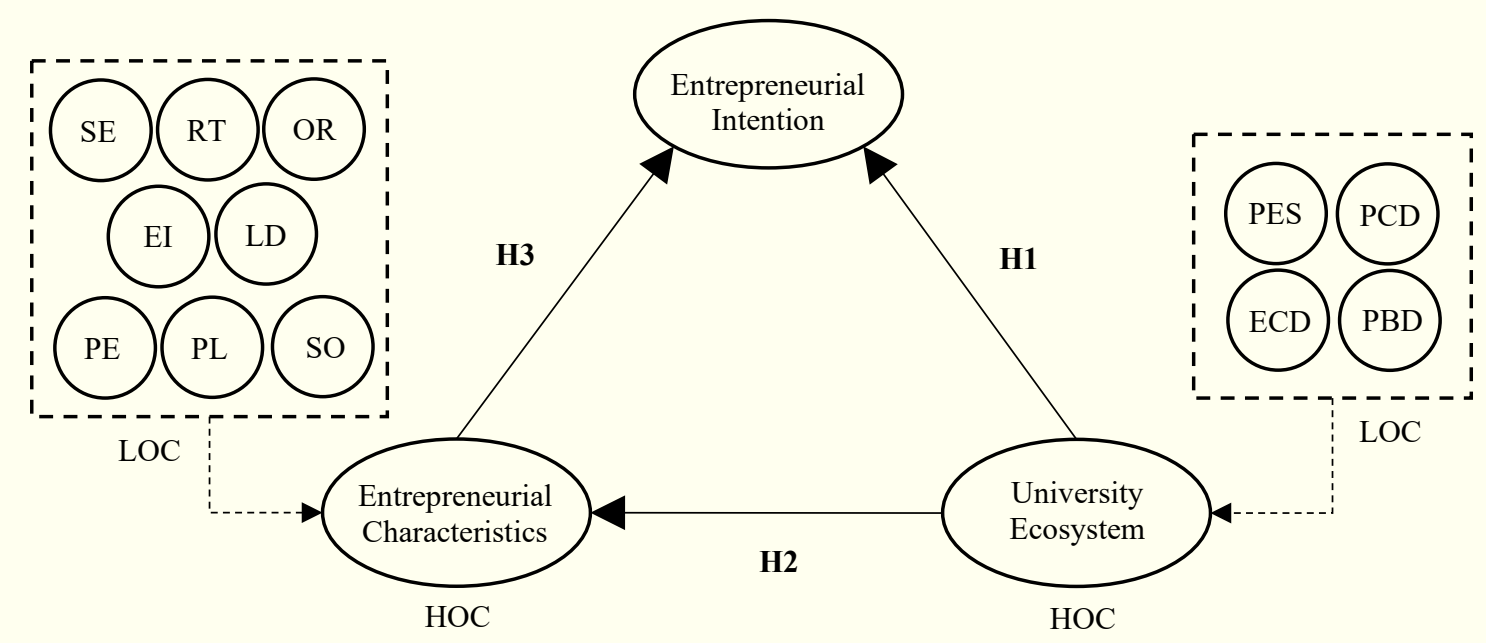

Figure 4. Second stage model in the two-stage approach.

The two-stage approach has the advantage of estimating a more parsimonious model, since there is no need to represent LOCs (Hair et al., 2018; Sarstedt et al., 2019), besides being more adequate when the researcher's interest lies only on the relationships between the HOCs (Becker et al., 2012; Sarstedt et al., 2019), which is the case of our research. Furthermore, our research model is classified as a one of 'hierarchical latent variables of a reflexive-formative' type (Becker et al., 2012; Chin \& Newsted, 1999; Sarstedt et al., 2019) containing only three latent variables: UE, EC, and EI. The LOCs are reflexive, while the HOCs are formative and fully mediate the influence of the LOCs toward entrepreneurial intention.

The UE latent variable can be defined as an arrangement of elements, pertaining to the sphere of universities and the higher education system in general, which interact with each other and the external environment to produce entrepreneurial activity, in other words, economic development through the commercialization of universities' inventions (Laguía González, Jaén, Topa, \& Moriano, 2019; Moraes et al., 2018; Mustafa et al., 2016; Rothaermel, Agung, \& Jiang, 2007). The EC latent variable, by its turn, is a set of personal traits commonly perceived on entrepreneurs and broadly discussed throughout the literature associated to the entrepreneurial mindset (Boyd \& Vozikis, 1994; Filion, 1994; Krakauer, Moraes, Coda, \& Berne, 2018; Markman \& Baron, 2003; Saeed et al., 2015; Schmidt \& Bohnenberger, 2009). Lastly, the EC latent variable can be defined as the conscious decision of engaging on a self-owned business venture and planning to do so in the future (Moraes et al., 2018; Mustafa et al., 2016; Thompson, 2009). It is important to stress that intention cannot be mistaken with action, although it is an

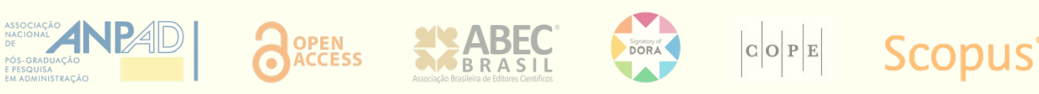


antecedent to the latter. Therefore, our model does not measure student's actual engagement on entrepreneurial activity, but their willingness to do so.

\section{RESULTS}

On this section, we explain the analysis of the model's results, which was divided into three major processes: (I) evaluation of measurement scales, (II) of the measurement model, and (III) of the structural model.

Firstly, concerning our measurement model (analysis process I), we employed the Smart PLS 3 software to conduct confirmatory factor analysis (CFA) in order to evaluate the psychometric properties of constructs (as recommended by Ringle \& Becker, 2015). This step was necessary to ensure indicators only contributed to the measurement of the construct they pertain to, thus adding to the reliability and validity of results and the quality of further assessments. Therefore, only measures with factor loads higher than or equal to 0.7 were kept in the model (as recommended by Hair et al., 2017). However, measures with factor loads higher than 0.4 and lower than 0.7 were subjected to further evaluation. For each of these measures, we assessed the impact of their exclusion on the average variance extraction (AVE) and on composite reliability (CR). Therefore, we only eliminated from the model measures that could negatively affect AVE and CR (as recommended by Hair et al., 2017). Thus, the SE1, SE5, RT1, IN3, LDI1, PE2, and SO3 indicators were excluded, leaving us with 55 indicators from the original survey questionnaire to continue analysis. The results of this step are demonstrated by Table 2 .

\section{Table 2}

Standardized CFA path loadings and descriptive statistics

\begin{tabular}{|c|c|c|c|c|c|c|c|}
\hline & & Questions & $\begin{array}{l}\text { Standard. } \\
\text { path loading }\end{array}$ & Mean & $\begin{array}{c}\text { Std. } \\
\text { deviation }\end{array}$ & $\begin{array}{l}\text { Critical } \\
\text { ratio }\end{array}$ & $\begin{array}{c}\mathrm{P}- \\
\text { value }\end{array}$ \\
\hline \multirow{4}{*}{ 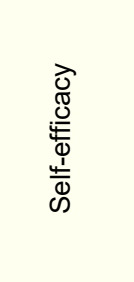 } & $(\mathrm{SE} 2)$ & I can originate new ideas and products & 0.766 & 0.765 & 0.023 & 33.742 & 0.000 \\
\hline & (SE3) & $\begin{array}{l}\text { I can develop and maintain favorable } \\
\text { relationship with potential investors }\end{array}$ & 0.749 & 0.748 & 0.026 & 29.013 & 0.000 \\
\hline & (SE4) & $\begin{array}{l}\text { I can see new market opportunities for new } \\
\text { products and services }\end{array}$ & 0.848 & 0.846 & 0.014 & 58.628 & 0.000 \\
\hline & (SE6) & $\begin{array}{l}\text { I can develop a working environment that } \\
\text { encourages people to try out something new }\end{array}$ & 0.552 & 0.550 & 0.044 & 12.494 & 0.000 \\
\hline \multirow{3}{*}{ 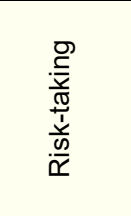 } & (RT2) & $\begin{array}{l}\text { I admit taking risks in exchange for possible } \\
\text { benefits }\end{array}$ & 0.740 & 0.739 & 0.034 & 21.791 & 0.000 \\
\hline & (RT3) & $\begin{array}{l}\text { My decisions are not predominantly based on } \\
\text { my comfort zone }\end{array}$ & 0.635 & 0.634 & 0.044 & 14.344 & 0.000 \\
\hline & (RT4) & $\begin{array}{l}\text { I believe that getting involved in situations of } \\
\text { higher risk will create results of great impact }\end{array}$ & 0.771 & 0.767 & 0.031 & 24.637 & 0.000 \\
\hline \multirow{2}{*}{ 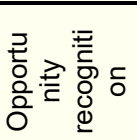 } & (OR1) & $\begin{array}{l}\text { I believe I have a good ability in recognizing } \\
\text { business opportunities }\end{array}$ & 0.838 & 0.837 & 0.014 & 57.845 & 0.000 \\
\hline & (OR2) & $\begin{array}{l}\text { I believe I have the skill to understand, } \\
\text { recognize, and make use of abstract data }\end{array}$ & 0.531 & 0.532 & 0.034 & 15.594 & 0.000 \\
\hline
\end{tabular}

Continues

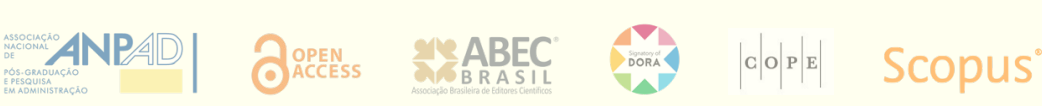


Table 2 (continued)

\begin{tabular}{|c|c|c|c|c|c|c|c|}
\hline \multirow{2}{*}{ 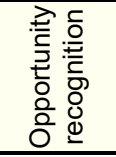 } & (OR3) & I am always up to any opportunity that may arise & 0.773 & 0.774 & 0.035 & 22.165 & 0.000 \\
\hline & (OR4) & $\begin{array}{l}\text { I feel able to identify business opportunities and } \\
\text { profit from them }\end{array}$ & 0.867 & 0.867 & 0.010 & 88.999 & 0.000 \\
\hline \multirow{5}{*}{ 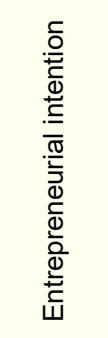 } & (El1) & $\begin{array}{l}\text { I am ready to do whatever it takes to be an } \\
\text { entrepreneur }\end{array}$ & 0.788 & 0.788 & 0.017 & 46.183 & 0.000 \\
\hline & $(\mathrm{El} 2)$ & $\begin{array}{l}\text { Even though I work for other companies, I will } \\
\text { never abandon my dream of opening my } \\
\text { business }\end{array}$ & 0.817 & 0.817 & 0.015 & 53.79 & 0.000 \\
\hline & (EI3) & $\begin{array}{l}\text { My greatest achievement will be to have my } \\
\text { own business }\end{array}$ & 0.871 & 0.871 & 0.011 & 77.795 & 0.000 \\
\hline & $(\mathrm{E} \mid 4)$ & $\begin{array}{l}\text { I will make every effort to create and maintain } \\
\text { my own company }\end{array}$ & 0.870 & 0.870 & 0.010 & 85.755 & 0.000 \\
\hline & $($ El5) & I intend to start a business in the coming years & 0.860 & 0.859 & 0.011 & 76.738 & 0.000 \\
\hline \multirow{3}{*}{ 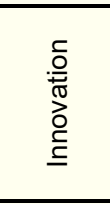 } & (IN1) & $\begin{array}{l}\text { I prefer a job full of novelty instead a routine } \\
\text { activity }\end{array}$ & 0.739 & 0.733 & 0.042 & 17.612 & 0.000 \\
\hline & (IN2) & $\begin{array}{l}\text { I like changing my way of work whenever } \\
\text { possible }\end{array}$ & 0.709 & 0.711 & 0.039 & 18.358 & 0.000 \\
\hline & (IN4) & $\begin{array}{l}\text { I bet on creativity while elaborating } \\
\text { projects/activities }\end{array}$ & 0.720 & 0.718 & 0.047 & 15.185 & 0.000 \\
\hline \multirow{4}{*}{ 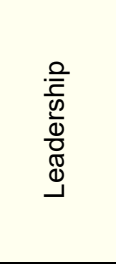 } & (LD2) & People respect my opinion & 0.719 & 0.717 & 0.033 & 21.618 & 0.000 \\
\hline & (LD3) & $\begin{array}{l}\text { I can convince people to overcome conflicts and } \\
\text { work as a team to achieve a particular result }\end{array}$ & 0.774 & 0.773 & 0.033 & 23.521 & 0.000 \\
\hline & (LD4) & $\begin{array}{l}\text { I can encourage people to perform tasks for } \\
\text { which they are unmotivated }\end{array}$ & 0.727 & 0.728 & 0.036 & 20.366 & 0.000 \\
\hline & (LD5) & $\begin{array}{l}\text { Frequently, people ask my opinion regarding } \\
\text { work or study issues }\end{array}$ & 0.667 & 0.664 & 0.04 & 16.674 & 0.000 \\
\hline \multirow{3}{*}{ 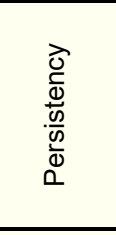 } & (PE1) & $\begin{array}{l}\text { Professionally, I consider myself more persistent } \\
\text { than others }\end{array}$ & 0.718 & 0.716 & 0.031 & 23.497 & 0.000 \\
\hline & (PE3) & $\begin{array}{l}\text { I'm capable of creating, conducting, and } \\
\text { implementing new life plans }\end{array}$ & 0.804 & 0.802 & 0.023 & 34.675 & 0.000 \\
\hline & (PE4) & $\begin{array}{l}\text { considering perseverance, imagination, and } \\
\text { creativity }\end{array}$ & 0.654 & 0.654 & 0.035 & 18.512 & 0.000 \\
\hline \multirow{4}{*}{ 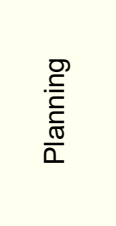 } & (PL1) & I always plan everything I do very carefully & 0.701 & 0.702 & 0.035 & 20.094 & 0.000 \\
\hline & $(\mathrm{PL} 2)$ & $\begin{array}{l}\text { To achieve my goals, I detail all the steps to be } \\
\text { followed }\end{array}$ & 0.759 & 0.759 & 0.030 & 25.476 & 0.000 \\
\hline & (PL3) & $\begin{array}{l}\text { I know I can set my short-, medium-, and long- } \\
\text { term goals }\end{array}$ & 0.708 & 0.701 & 0.034 & 21.018 & 0.000 \\
\hline & (PL4) & I like to set goals and targets to feel challenged & 0.718 & 0.715 & 0.033 & 21.556 & 0.000 \\
\hline \multirow{3}{*}{$\begin{array}{l}\frac{3}{0} \\
\frac{.0}{0.0} \\
\frac{.0}{0} \\
\infty\end{array}$} & (SO1) & $\begin{array}{l}\text { The social contacts that I have are very } \\
\text { important for my personal life }\end{array}$ & 0.654 & 0.651 & 0.053 & 12.425 & 0.000 \\
\hline & (SO2) & $\begin{array}{l}\text { I know several people who could assist me } \\
\text { professionally, if I needed it }\end{array}$ & 0.723 & 0.720 & 0.040 & 18.168 & 0.000 \\
\hline & (SO4) & $\begin{array}{l}\text { I try to maintain constant contact with people in } \\
\text { my network }\end{array}$ & 0.824 & 0.821 & 0.029 & 28.285 & 0.000 \\
\hline \multirow{5}{*}{ 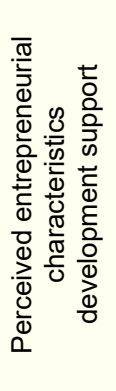 } & (ECD1) & $\begin{array}{l}\text { The university ecosystem helped me identify } \\
\text { business opportunities }\end{array}$ & 0.711 & 0.710 & 0.025 & 28.714 & 0.000 \\
\hline & (ECD2) & $\begin{array}{l}\text { The university ecosystem helped me be } \\
\text { persistent }\end{array}$ & 0.699 & 0.700 & 0.024 & 28.931 & 0.000 \\
\hline & (ECD3) & $\begin{array}{l}\text { The university ecosystem developed my } \\
\text { leadership skills through group work }\end{array}$ & 0.720 & 0.719 & 0.023 & 31.862 & 0.000 \\
\hline & (ECD4) & $\begin{array}{l}\text { The university ecosystem provided me with } \\
\text { planning and strategy tasks in different } \\
\text { disciplines, developing my ability to plan }\end{array}$ & 0.737 & 0.735 & 0.022 & $33 . .99$ & 0.000 \\
\hline & (ECD5) & $\begin{array}{l}\text { The university ecosystem enhanced my ability } \\
\text { to innovate }\end{array}$ & 0.791 & 0.790 & 0.015 & 52.907 & 0.000 \\
\hline
\end{tabular}




\section{Table 2 (Continued)}

\begin{tabular}{|c|c|c|c|c|c|c|c|}
\hline \multirow{3}{*}{ 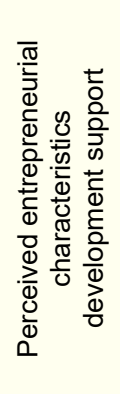 } & (ECD7) & $\begin{array}{l}\text { The university ecosystem has enabled me to } \\
\text { relate and analyze the variables that influence } \\
\text { the result of a problem, increasing my ability to } \\
\text { take calculated risks } \\
\text { The university ecosystem provided me with } \\
\text { several important contacts both personally and } \\
\text { professionally }\end{array}$ & 0.652 & 0.652 & 0.025 & 26.001 & 0.000 \\
\hline & (ECD8) & $\begin{array}{l}\text { The university ecosystem motivated me to } \\
\text { desire opening my own business }\end{array}$ & 0.662 & 0.660 & 0.030 & 22.144 & 0.000 \\
\hline & (ECD9) & $\begin{array}{l}\text { The university ecosystem developed my skills to } \\
\text { conduct a new business opportunity }\end{array}$ & 0.757 & 0.757 & 0.021 & 35.760 & 0.000 \\
\hline \multirow{4}{*}{ 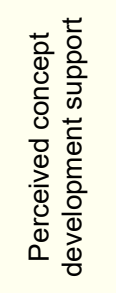 } & (PCD1) & $\begin{array}{l}\text { My university creates awareness of } \\
\text { entrepreneurship as a possible career choice }\end{array}$ & 0.850 & 0.849 & 0.021 & 40.826 & 0.000 \\
\hline & (PCD2) & $\begin{array}{l}\text { My university motivates students to start a new } \\
\text { business }\end{array}$ & 0.874 & 0.872 & 0.021 & 41.143 & 0.000 \\
\hline & (PCD3) & $\begin{array}{l}\text { My university provides students with ideas to } \\
\text { start a new business }\end{array}$ & 0.883 & 0.882 & 0.016 & 53.544 & 0.000 \\
\hline & (PCD4) & $\begin{array}{l}\text { My university provides students with the } \\
\text { knowledge needed to start a new business }\end{array}$ & 0.816 & 0.814 & 0.028 & 29.338 & 0.000 \\
\hline \multirow{3}{*}{ 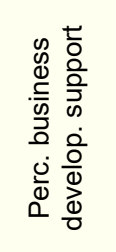 } & (PBD1) & $\begin{array}{l}\text { My university provides students with the } \\
\text { financial means to start a new business }\end{array}$ & 0.818 & 0.816 & 0.037 & 22.046 & 0.000 \\
\hline & (PBD2) & $\begin{array}{l}\text { My university uses its reputation to support } \\
\text { students that start a new business }\end{array}$ & 0.761 & 0.761 & 0.047 & 16.146 & 0.000 \\
\hline & (PBD3) & $\begin{array}{l}\text { My university serves as a lead customer of } \\
\text { students that start a new business }\end{array}$ & 0.885 & 0.882 & 0.021 & 42.581 & 0.000 \\
\hline \multirow{6}{*}{ 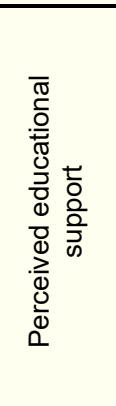 } & (PES1) & $\begin{array}{l}\text { My university offers elective courses on } \\
\text { entrepreneurship }\end{array}$ & 0.762 & 0.743 & 0.05 & 15.324 & 0.000 \\
\hline & (PES2) & $\begin{array}{l}\text { My university offers project work focused on } \\
\text { entrepreneurship }\end{array}$ & 0.836 & 0.825 & 0.030 & 27.799 & 0.000 \\
\hline & (PES3) & $\begin{array}{l}\text { My university offers internship focused on } \\
\text { entrepreneurship }\end{array}$ & 0.650 & 0.647 & 0.055 & 11.853 & 0.000 \\
\hline & (PES4) & $\begin{array}{l}\text { My university offers a bachelor or master study } \\
\text { on entrepreneurship }\end{array}$ & 0.625 & 0.623 & 0.058 & 10.751 & 0.000 \\
\hline & (PES5) & $\begin{array}{l}\text { My university arranges conferences/workshops } \\
\text { on entrepreneurship }\end{array}$ & 0.735 & 0.735 & 0.052 & 14.046 & 0.000 \\
\hline & (PES6) & $\begin{array}{l}\text { My university brings entrepreneurial students in } \\
\text { contact with each other }\end{array}$ & 0.731 & 0.733 & 0.054 & 13.529 & 0.000 \\
\hline
\end{tabular}

After evaluating the measurement scales, we proceeded to evaluate the measurement model (analysis process II). Here, we conducted a two-part analysis on the complete set of samples. On the first part, we tested the model's LOCs for (a) convergent and (b) discriminant validity, (c) internal consistency, and (d) indicator reliability. On the second part, we conducted the same process of analysis for the HOCs with the inclusion of (e) collinearity and (f) significance and relevance tests.

In terms of convergent validity (a), all indicators' factorial loads scored above 0.7 and were greater than the cross loads with other LOCs (as recommended by Hair et al., 2017). Discriminant validity (b), on the other hand, was assessed by means of AVE and an internal consistency measure (c) represented by Cronbach's alpha. In this regard, all AVE and Cronbach's alpha values scored above the threshold of 0.5 (as recommended by Hair, Ringle, \& Sarstedt, 2011). 
Besides the evaluation of factorial loads, we assessed the composite reliability (d) of each construct, which is referenced by the threshold of 0.7 and described as the degree to which the indicators represent a common latent construct (Hair et al., 2017; Hair et al., 2018). Table 3 presents the summary of the model's evaluation results.

\section{Table 3}

\section{Evaluation of the measurement model}

\begin{tabular}{|c|c|c|c|c|c|c|c|c|c|c|c|c|c|}
\hline Indicators & SE & RT & OR & EI & IN & LD & PE & PL & so & ECD & PCD & PBD & PES \\
\hline SE & 0.737 & & & & & & & & & & & & \\
\hline RT & 0.317 & 0.718 & & & & & & & & & & & \\
\hline OR & 0.612 & 0.406 & 0.764 & & & & & & & & & & \\
\hline El & 0.349 & 0.347 & 0.593 & 0.842 & & & & & & & & & \\
\hline IN & 0.427 & 0.425 & 0.442 & 0.298 & 0.723 & & & & & & & & \\
\hline LD & 0.435 & 0.325 & 0.396 & 0.175 & 0.287 & 0.723 & & & & & & & \\
\hline PE & 0.455 & 0.415 & 0.590 & 0.409 & 0.438 & 0.497 & 0.728 & & & & & & \\
\hline PL & 0.297 & 0.313 & 0.385 & 0.187 & 0.329 & 0.445 & 0.546 & 0.722 & & & & & \\
\hline so & 0.343 & 0.310 & 0.358 & 0.205 & 0.267 & 0.352 & 0.363 & 0.274 & 0.737 & & & & \\
\hline ECD & 0.225 & 0.159 & 0.282 & 0.187 & 0.125 & 0.269 & 0.265 & 0.225 & 0.234 & 0.721 & & & \\
\hline PCD & 0.058 & 0.047 & 0.099 & 0.040 & 0.033 & 0.122 & 0.080 & 0.130 & 0.091 & 0.596 & 0.856 & & \\
\hline PBD & 0.063 & 0.032 & 0.049 & -0.036 & -0.004 & 0.157 & 0.127 & 0.114 & 0.100 & 0.553 & 0.630 & 0.823 & \\
\hline PES & 0.110 & 0.021 & 0.087 & 0.012 & 0.021 & 0.071 & 0.063 & 0.119 & 0.097 & 0.515 & 0.690 & 0.573 & 0.726 \\
\hline Cronbach's alpha & 0.722 & 0.530 & 0.756 & 0.897 & 0.546 & 0.696 & 0.558 & 0.696 & 0.589 & 0.884 & 0.879 & 0.761 & 0.826 \\
\hline Composite reliability & 0.823 & 0.760 & 0.845 & 0.924 & 0.766 & 0.814 & 0.771 & 0.813 & 0.779 & 0.907 & 0.916 & 0.863 & 0.869 \\
\hline $\begin{array}{c}\text { Average variance } \\
\text { extracted }\end{array}$ & 0.543 & 0.515 & 0.583 & 0.708 & 0.522 & 0.523 & 0.530 & 0.521 & 0.543 & 0.520 & 0.733 & 0.677 & 0.528 \\
\hline
\end{tabular}

The second part of the measurement model analysis involved saving the first part scores and adding them as new variables to the dataset (as recommended by Hair et al., 2018; Sarstedt et al., 2019). Therefore, on this step, we took into account only the model's HOCs (as seen on Figure 4): one reflexive construct (EI) and two formative ones (EC and UE). With this in mind, the same analysis criteria utilized in the first step are applicable to assessing the reflexive EI construct on this second step, which resulted on the following: Cronbach's alpha $=0.898 ; \mathrm{CR}=0.924 ; \mathrm{AVE}$ $=0.710$. Therefore, all indicators are within established parameters.

With respect to the collinearity of indicators, (e) we calculated the formative indicator's variance inflation factor (VIF). All scores remained below five, which is within established parameters (Hair et al., 2017). Significance and relevance (f), by their turn, were analyzed with the use of the bootstrapping technique (Efron \& Tibshiranit, 1994). Thus, we assessed the T statistics of the outer weights and, when necessary, the outer loadings of variables. The result of this analysis, which reveals the importance of each LOC for their respective HOC, is demonstrated by Table 4 . 


\section{Table 4}

Outer weights of the formative HOCs

\begin{tabular}{ccc}
\hline Indicators & Entrepreneurial Characteristics & University Ecosystem \\
\hline SE & -0.040 & \\
RT & 0.198 & \\
OR & 0.836 & \\
IN & 0.033 & \\
L & -0.076 & \\
PE & 0.194 & \\
PL & -0.097 & \\
SO & 0.039 & 1.275 \\
ECD & & -0.170 \\
PCD & & -0.572 \\
PBD & & -0.058 \\
PES & & \\
\hline
\end{tabular}

Lastly, before assessing the structural model (analysis process III), it is necessary to evaluate its (g) collinearity before moving on to the (h) significance assessment. Therefore, the VIF values for each subpart of the model were calculated and found to be within the established parameters (bellow five, as recommended by Hair et al., 2017), thus attesting to the collinearity of the EU and EC.

In order to analyze the significance of indicators (h), the bootstrapping technique was used. This method is not only based on an estimation of the model, but in the calculation of parameter estimates and their trust intervals based on multiple estimations (Hair et al., 2017). The T statistics distribution analyzes the hypothesis that path coefficients are significant. In the event of results presenting values above 1.96, the null hypothesis is rejected, and the path coefficient is considered significant (Efron \& Tibshiranit, 1994; Hair et al., 2017). Table 5 presents the value of coefficients between constructs and their respective $T$ statistics scores.

\section{Table 5}

Coefficients of the structural model - between constructs

\begin{tabular}{lcccc}
\multicolumn{1}{c}{ Path } & Sample Mean & Standard Deviation & T-Statistics & P-Values \\
\hline University Ecosystem $\rightarrow$ Entrepreneurial Characteristics & 0.317 & 0.036 & 8.599 & 0.000 \\
University Ecosystem $\rightarrow$ Entrepreneurial Intention & 0.064 & 0.030 & 2.205 & 0.028 \\
Entrepreneurial Characteristics $\rightarrow$ Entrepreneurial Intention & 0.603 & 0.025 & 24.327 & 0.000 \\
\hline
\end{tabular}

As demonstrated, every $\mathrm{T}$ statistic value is above 1.96, thus supporting hypotheses 1,2 , and 3 . The complete model resulting from our empirical approach is presented in Figure 5. 


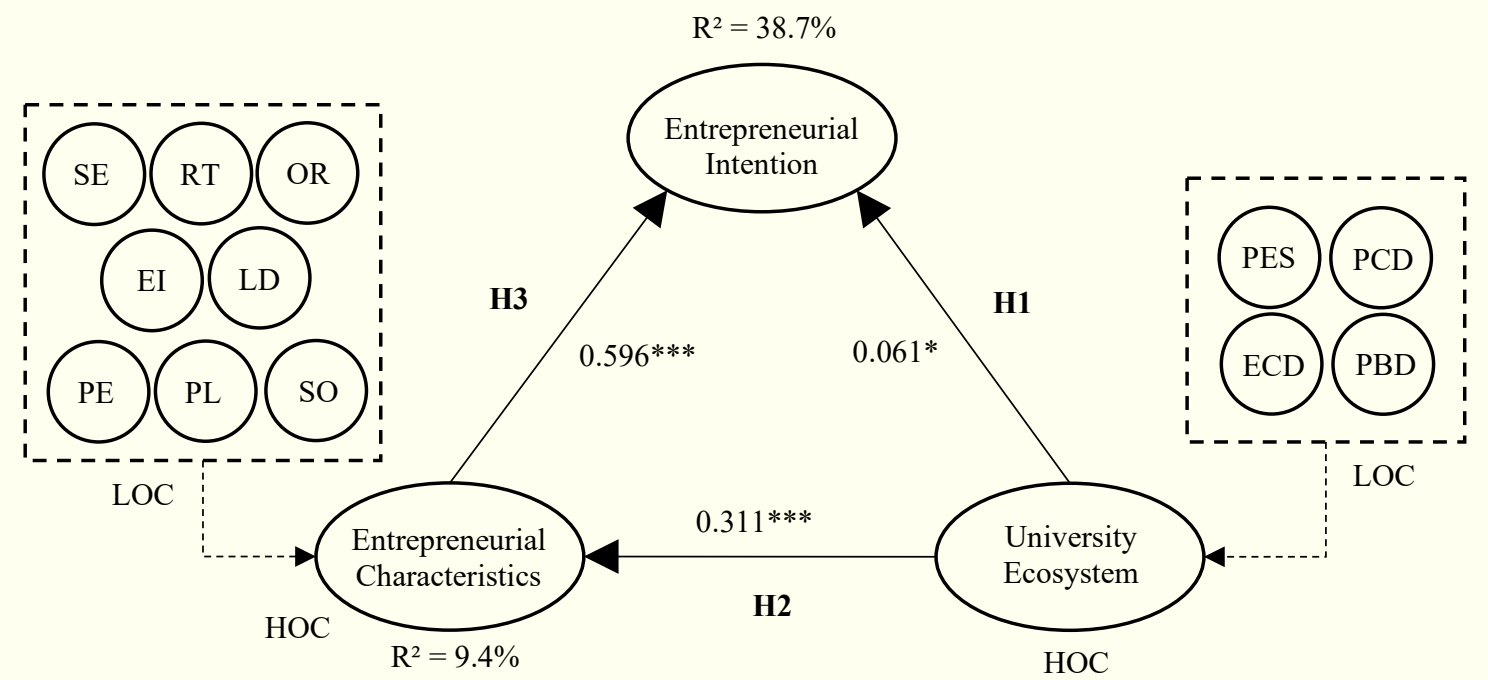

Note $1: *=$ significant at $5 \% ; * *=$ significant at $1 \% ; * * *=$ significant at $0.1 \%$; NS $=$ not significant.

Figure 5. Complete empirical model.

According to Cohen (1988) and Faul, Erdfelder, Buchner, and Lang (2009), R ${ }^{2}$ values ranging $2 \%-13 \%, 13 \%-35 \%$, and above $25 \%$ are considered to be, respectively, of small, medium, and large effects. Calculations showed that the entrepreneurial intention construct presented an $\mathrm{R}^{2}$ of 0.387 (high effect), and the entrepreneurial characteristics construct presented an $\mathrm{R}^{2}$ of 0.094 (small effect). Besides using $\mathrm{R}^{2}$ to evaluate predictive precision, $\mathrm{Q}^{2}$, which is an indicator of predictive relevance, was also calculated and it results values above zero (Hair et al., 2017).

\section{DISCUSSION OF RESULTS}

The complete empirical model (Figure 5) allows us to confirm that an ESUE, represented by the University Ecosystem construct, presents a positive influence on student's entrepreneurial intention, which is coherent with the literature (Abualbasal \& Badran, 2019; Morris et al., 2017). Entrepreneurial Intention scored an $\mathrm{R}^{2}$ value of $38.7 \%$, which is considered high for social sciences (Cohen, 1988; Faul et al., 2009), for it indicates that a sizeable portion of variance is captured by the model. However, despite being positive, the effect of UE on EI is marginal when compared to the effect of EC on EI. This means that student's intention to develop entrepreneurial action is much more related to their own personal characteristics than to the university's entrepreneurial push mechanisms (a term used by Wegner, Thomas, Teixeira, \& Maehler, 2019). Moreover, UE exerts a greater influence on EC than on EI, thus playing a larger role in the formation of student's entrepreneurial mindset.

On a second note, the outer weighs of HOCs allow us to have a deeper understanding of the contribution of UE and EC to EI. Our study revealed that one positive aspect of an ESUE is the entrepreneurial characteristics development support. ECD was the single LOC presenting a strong, positive outer weigh score (Table 4), indicating that students acknowledge the university's 
contribution in developing their own entrepreneurial mindsets and personality traits. On the other hand, perceived educational support, concept development support, and business development support are considered negative aspects of this same ESUE. As such, two initial possibilities present themselves: either there is lack of mechanisms for delivering these forms of support (such as entrepreneurship oriented programs, internships, courses, subjects, incubation programs, etc.) or the method of delivery is sub-par to the point that students are discouraged from pursuing entrepreneurial careers (hence the negative outer weighs).

Using the outer weighs results once more, and moving our attention to EC, it is clear that opportunity recognition is the prevalent entrepreneurial characteristic for students - an indication that they perceive themselves as capable of identifying good opportunities and the means to profit from them, which could be related to the development of analytic capabilities provided by the university. Risk-taking and persistency, by their turn, are the next prevailing characteristics, but on a lesser degree when compared to opportunity recognition. Lastly, innovation and sociability are the last positive contributors to EC, but only marginally. Selfefficacy, leadership, and planning, on the other hand, present a negative importance to EC, meaning these characteristics actually dissuade students from wanting to become entrepreneurs.

It is important to stress that these results refer to the complete empirical model. The analysis of the outer weighs of HOCs can also help in cross-context comparisons. Although it was not the aim of this study to test regional differences, we can use this form of analysis to look for specificities within each of the macro-regions in the sample. Table 4 provides us with a profile of the most influential UE support structures and EI. Even though the complete empirical model gives us the general answer to the research's hypothesis, the outer weights provide us with a more detailed profile in terms of HOCs. Furthermore, even though our sample is not representative of all Brazilian public universities, it still respects the minimum number of samples per macroregion, which increases our reliability in the results. Thus, it is clear that the students participating in the sample have an intrinsic motivation for entrepreneurship.

\section{CONCLUSIONS AND FINAL REMARKS}

The notion that the university ecosystem is an important factor for stimulating student entrepreneurship is a well-known and studied concept (see Jansen, van de Zande, Brinkkemper, Stam, \& Varma 2015; Muscio \& Ramaciotti 2019; Peterman \& Kennedy 2003; Souitaris, Zerbinati, \& Al-Laham, 2007) - one which found confirmation on our study. However, this stimulus is not homogenous across different environments.

The main contribution of this research is providing a conceptual model for assessing the influence of an entrepreneurship supportive university ecosystem on student's entrepreneurial intentions. Although our results pertain to a specific scenario, the model is capable of producing interpretations about a worldwide phenomenon. By means of a countrywide level analysis on a developing nation context, we have empirically demonstrated the effectiveness of the model in

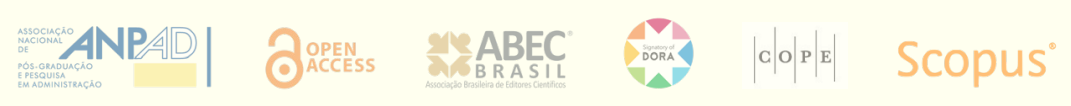


revealing the extent of the university's reach in terms of promoting entrepreneurship among students and separating it from their own intrinsic entrepreneurial drive.

In the case of Brazil, the university ecosystem presents a positive, yet marginal, contribution to student's entrepreneurial intention. Their willingness to become entrepreneurs stems, in fact, from their own entrepreneurial characteristics. Furthermore, the model is also capable of providing a deeper analysis of this situation. The only university entrepreneurship support structure to effectively contribute to student's entrepreneurial intention was perceived entrepreneurial characteristics support. This notion provides basis for questioning the current model adopted by Brazilian public universities. Far from stating that these are not conducive of entrepreneurial outcomes, model results allow us question the effectiveness by which this happens. Our evidences point to the possibility that the stimuli for helping students start their own business is either underexplored or ineffective at all. If it is underexplored, changes in the entrepreneurship supportive arrangements of the university ecosystem would suffice to better influence student's entrepreneurial intention. However, if it is ineffective, then perhaps the university should concentrate its efforts on reinforcing the entrepreneurial characteristics of students. By doing this, it could redirect its entrepreneurial support mechanisms toward students whose intention arise from their own entrepreneurial characteristics, thus increasing the likelihood of sparking entrepreneurial intention.

Perhaps in different educational contexts, such as the USA and Europe, results might differ because of specificities in the UE. In the case of Brazil, students did not perceive much support from the university in terms of actually developing businesses (as exemplified by the low scores for PES, PCD, and PBD on Table 4). In high-income countries, support structures for business development, such as funding, incubation structure, and overall connection with the industry, might be stronger motivators than just the student's own entrepreneurial characteristics. Although the sampled universities are among the most entrepreneurial higher education institutions in Brazil, and, therefore, adopt similar policies than the ones abroad, there is still a difference in the intensity of student entrepreneurial activity.

Undoubtedly, in order to make such an assertion, we would have to address some limitations of this research. First, we obtained our results by means of a select number of HEIs in Brazil, a continent-sized country with many different local contexts, and not all states participated on the sample. Therefore, we can expect that a more accurate picture of the national scenario could be obtained by broadening the sample. Second, indicators only represent perceptions of Business Administration students, a known bias of this research. Results could benefit from collecting data on other courses, thus contributing to the robustness of our findings, especially in terms of the effectiveness of different entrepreneurship push mechanisms to describe every action the university employs with the intention of fostering entrepreneurship. Moreover, we only collected data from public universities. Perhaps the private scenario could yield different results.

As an avenue for future research, we suggest utilizing the model for comparative analysis of different courses and contexts. Other curricula than Business Administration could stimulate student's entrepreneurial intention in a different way than what we have shown in our results,

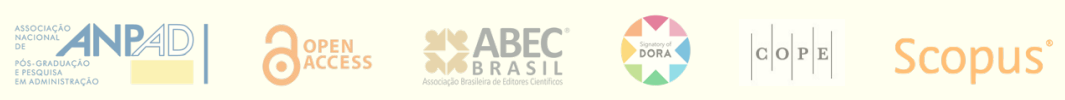


even within the same university ecosystem. Furthermore, the model could be applied for comparing different educational contexts and shed light on possible differences between university ecosystems, either between regions or between countries.

In this regard, our empirical model and measurement instrument can both be applied to different contexts and produce profiles for comparison. Still, results could benefit from a further exploration of the regional entrepreneurial ecosystems - in terms of their barriers and enablers - to better fit universities within them, thus providing a much more accurate picture of the ecosystem's reach isolated from contextual factors.

\section{REFERENCES}

Abualbasal, A. M., \& Badran, R. E. (2019). Student's attitude towards entrepreneurship at Princess Sumaya University for Technology. Journal of Entrepreneurship Education, 22(1). Retrieved from https://search.proquest.com/scholarly-journals/students-attitude-towards-entrepreneurshipat/docview/2238486373/se-2? accountid $=8113$

Ahmed, T., Chandran, V. G. R., \& Klobas, J. (2017). Specialized entrepreneurship education: Does it really matter? Fresh evidence from Pakistan. International Journal of Entrepreneurial Behaviour and Research, 23(1), 4-19. https://doi.org/10.1108/IJEBR-01-2016-0005

Ajzen, I. (1991). The Theory of Planned Behavior. Organizational Behaviour and Human Decision Processes, 50, 179211. https://doi.org/10.1016/0749-5978(91)90020-T

Al-Jubari, I., Hassan, A., \& Liñán, F. (2018). Entrepreneurial intention among University students in Malaysia: integrating self-determination theory and the theory of planned behavior. International Entrepreneurship and Management Journal, 15, 1323-1342. https://doi.org/10.1007/s11365-018-0529-0

Al-Shammari, M., \& Waleed, R. (2018). Entrepreneurial intentions of private university students in the kingdom of Bahrain. International Journal of Innovation Science, 10(1), 43-57. https://doi.org/10.1108/IJIS-06-2017-0058

Alves, A. C., Fischer, B., Schaeffer, P. R., \& Queiroz, S. (2019). Determinants of student entrepreneurship: An assessment on higher education institutions in Brazil. Innovation $\mathcal{E}$ Management Review, 16(2), 96-117. https://doi.org/10.1108/INMR-02-2018-0002

Alves, A. da S., Quelhas, O. L. G., Silva, M. H. T. da, \& Lameira, V. de J. (2015). On the role of university in the promotion of innovation: Exploratory evidences from a university-industry cooperation experience in Brazil. International Journal of Innovation and Learning, 17(1), 1-18. https://doi.org/10.1504/IJIL.2015.066061

Amadei, J. R., Torkomian, A. L. (2009). As patentes nas universidades: análise dos depósitos das universidades públicas paulistas. Ciência da Informação, 38(2), 9-18. https://doi.org/10.1590/S0100-19652009000200001

Audretsch, D. B., Cunningham, J. A., Kuratko, D. F., Lehmann, E. E., \& Menter, M. (2019). Entrepreneurial ecosystems: economic, technological, and societal impacts. Journal of Technology Transfer, 44(2), 313-325. https://doi.org/10.1007/s10961-018-9690-4

Audretsch, D. B., \& Link, A. N. (2017). Embracing an entrepreneurial ecosystem: an analysis of the governance of research joint ventures. Small Business Economics, 52, 429-436. https://doi.org/10.1007/s11187-017-9953-8

Barbosa, S. D., Gerhardt, M. W., \& Kickul, J. R. (2007). The Role of Cognitive Style and Risk Preference on Entrepreneurial Self-Efficacy and Entrepreneurial Intentions. Journal of Leadership $\mathcal{E}$ Organizational Studies, 13(4), 86-104. https://doi.org/10.1177/10717919070130041001

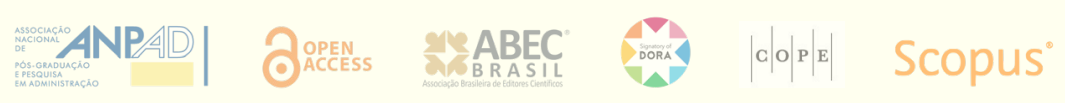


Barral, M. R. M., Ribeiro, F. G., \& Canever, M. D. (2018). Influence of the university environment in the entrepreneurial intention in public and private universities. RAUSP Management Journal, 53(1), 122-133. https://doi.org/10.1016/j.rauspm.2017.12.009

Becker, J.-M., Klein, K., \& Wetzels, M. (2012). Hierarchical latent variable models in PLS-SEM: Guidelines for Using Reflective-Formative Type models. Long Range Planning, 45(5-6), 359-394. https://doi.org/10.1016/j.lrp.2012.10.001

Boyd, N. G., \& Vozikis, G. S. (1994). The influence of self-efficacy on the development of entrepreneurial intentions and actions. Entrepreneurship Theory and Practice, 18(4), 63-77. https://doi.org/10.1177/104225879401800404

Brasil Júnior. (2019). Ranking de Universidades Empreendedoras. Retrieved from https://universidadesempreendedoras.org/ranking/

Brown, R., \& Mason, C. (2017). Looking inside the spiky bits: a critical review and conceptualisation of entrepreneurial ecosystems. Small Business Economics, 49(1), 11-30. https://doi.org/10.1007/s11187-017-9865-7

Bruton, G. D., Ketchen, D. J., \& Ireland, R. D. (2013). Entrepreneurship as a solution to poverty. Journal of Business Venturing, 28(6), 683-689. https://doi.org/10.1016/j.jbusvent.2013.05.002

Clark, B. R. (2003). Sustaining change in universities: Continuities in case studies and concepts. Tertiary Education and Management, 9(2), 99-116. Retrieved from https://www.researchgate.net/publication/44834504_SustainIng_Change_in_Universities_Continuities_in_C ase_Studies_and_Concepts

Chin, W. W., \& Newsted, P. R. (1999). Structural equation modeling analysis with small samples using partial least squares. Statistical Strategies for Small Sample Research, 1(1), 307-341.

Chiru, C., Tachiciu, L., \& Ciuchete, S. G. (2012). Psychological factors, behavioural variables and acquired competencies in entrepreneurship education. Procedia - Social and Behavioral Sciences, 46, 4010-4015. https://doi.org/10.1016/j.sbspro.2012.06.188

Cohen, J. (1988). Statistical power analysis for the social sciences (2nd ed.). Mahwah, NJ: Lawrence Erlbaum Associates.

Colombelli, A., Paolucci, E., \& Ughetto, E. (2019). Hierarchical and relational governance and the life cycle of entrepreneurial ecosystems. Small Business Economics, 52(2), 505-521. https://doi.org/10.1007/s11187-0179957-4

Dalmarco, G., Hulsink, W., \& Blois, G. V. (2018). Creating entrepreneurial universities in an emerging economy: Evidence from Brazil. Technological Forecasting and Social Change, 135, 99-111. https://doi.org/10.1016/j.techfore.2018.04.015

Davey, T., Rossano, S., \& van der Sijde, P. (2016). Does context matter in academic entrepreneurship? The role of barriers and drivers in the regional and national context. Journal of Technology Transfer, 41(6), 1457-1482. https://doi.org/10.1007/s10961-015-9450-7

Detienne, D. R., \& Chandler, G. N. (2004). opportunity identification and its role in the entrepreneurial classroom: A pedagogical approach and empirical test. Academy of Management Learning and Education, 3(3), 242-257. https://doi.org/10.5465/amle.2004.14242103

Duruflé, G., Hellmann, T., \& Wilson, K. (2018). Catalysing entrepreneurship in and around universities. Oxford Review of Economic Policy, 34(4), 615-636. https://doi.org/10.1093/oxrep/gry015

Efron, B., \& Tibshiranit, R. J. (1994). An introduction to the bootstrap. Boca Raton, FL: Chapman \& Hall/CRC.

Faul, F., Erdfelder, E., Buchner, A., \& Lang, A.-G. (2009). Statistical power analyses using G*Power 3.1: Tests for correlation and regression analyses. Behavior Research Methods, 41(4), 1149-1160. https://doi.org/10.3758/BRM.41.4.1149

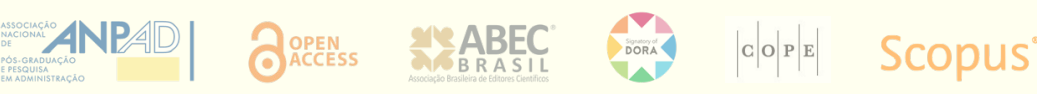


Ferrandiz, J., Fidel, P., \& Conchado, A. (2018). Promoting entrepreneurial intention through a higher education program integrated in an entrepreneurship ecosystem. International Journal of Innovation Science, 10(1), 6-21. https://doi.org/10.1108/IJIS-09-2017-0089

Filion, L. J. (1994). Entrepreurship and management: Differing but complementary processes. https://www.researchgate.net/publication/265320781

Fischer, B. B., Moraes, G. H. S. M. de, \& Schaeffer, P. R. (2019). Universities' institutional settings and academic entrepreneurship: Notes from a developing country. Technological Forecasting and Social Change, 147, $243-252$. https://doi.org/10.1016/j.techfore.2019.07.009

Freel, M., Persaud, A., \& Chamberlin, T. (2019). Faculty ideals and universities' third mission. Technological Forecasting and Social Change, 147, 10-21. https://doi.org/10.1016/j.techfore.2019.06.019

Global Entrepreneurship Monitor. (2019). Entrepreneurial intentions: Most recent data. https://www.gemconsortium.org/data

Ghio, N., Guerini, M., \& Rossi-Lamastra, C. (2019). The creation of high-tech ventures in entrepreneurial ecosystems: exploring the interactions among university knowledge, cooperative banks, and individual attitudes. Small Business Economics, 52(2), 523-543. https://doi.org/10.1007/s11187-017-9958-3

Gieure, C., Benavides-Espinosa, M. del M., \& Roig-Dobón, S. (2019). Entrepreneurial intentions in an international university environment. International Journal of Entrepreneurial Behaviour and Research, 25(8), 1605-1620. https://doi.org/10.1108/IJEBR-12-2018-0810

Hair, J. F., Hult, G. T. M., Ringle, C. M., \& Sarstedt, M. (2017). A Primer on Partial Least Squares Structural Equation Modeling (PLS-SEM). Retrieved from https://us.sagepub.com/en-us/nam/a-primer-on-partial-least-squaresstructural-equation-modeling-pls-sem/book244583

Hair, J., Ringle, C., \& Sarstedt, M. (2011). PLS-SEM: Indeed a Silver Bullet. Journal of Marketing Theory and Practice, 19, 139-151. https://doi.org/https://doi.org/10.2753/MTP1069-6679190202

Hair, Joseph F., Sarstedt, M., Ringle, C. M., \& Gudergan, S. P. (2018). Advanced Issues in Partial Least Squares Structural Equation Modeling. Retrieved from https://us.sagepub.com/en-us/nam/advanced-issues-in-partial-least-squaresstructural-equation-modeling/book243803

Hayter, C. S., Nelson, A. J., Zayed, S., \& O’Connor, A. C. (2018). Conceptualizing academic entrepreneurship ecosystems: A review, analysis and extension of the literature. Journal of Technology Transfer, 43(4), 1039-1082. https://doi.org/10.1007/s10961-018-9657-5

Instituto Brasileiro de Geografia e Estatística (2019). Projeção da população do Brasil e das Unidades da Federação. https://www.ibge.gov.br/apps/populacao/projecao/index.html

Instituto Nacional de Estudos e Pesquisas Educacionais Anísio Teixeira. (2018). Dados do Censo da Educação Superior. Censo Da Educação Superior. Retrieved from http://portal.inep.gov.br/artigo//asset_publisher/B4AQV9zFY7Bv/content/dados-do-censo-da-educacao-superior-as-universidades-brasileirasrepresentam-8-da-rede-mas-concentram-53-das-matriculas/21206

Instituto Nacional de Estudos e Pesquisas Educacionais Anísio Teixeira (2019). Sinopses Estatísticas da Educação Superior - Graduação. http://portal.inep.gov.br/web/guest/sinopses-estatisticas-da-educacao-superior

Jansen, S., Van De Zande, T., Brinkkemper, S., Stam, E., \& Varma, V. (2015). How education, stimulation, and incubation encourage student entrepreneurship: Observations from MIT, IIIT, and Utrecht University. The International Journal of Management Education, 13(2), 170-181. https://doi.org/10.1016/j.ijme.2015.03.001

INOVA. (2018). Faturamento de empresas-filhas da Unicamp ultrapassa R \$ 4,8 bilhões. Unicamp. Retrieved from https://www.inova.unicamp.br/noticias-inova/faturamento-de-empresas-filhas-da-unicamp-ultrapassa-r-48bilhoes/

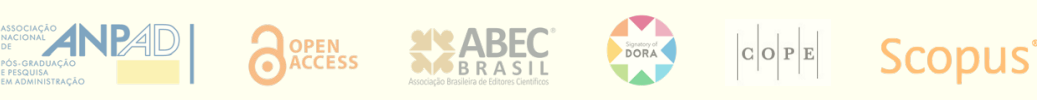


Isemberg, D. J. (2010). The big idea: How to start an entrepreneurial revolution. Harvard Business Review, 12. https://hbr.org/2010/06/the-big-idea-how-to-start-an-entrepreneurial-revolution

Karim, M. S. A. (2016). Entrepreneurship education in an engineering curriculum. Procedia Economics and Finance, 35, 379-387. https://doi.org/10.1016/s2212-5671(16)00047-2

Krakauer, P. V. de C., Moraes, G. H. S. M. de, Coda, R., \& Berne, D. de F. (2018). Brazilian women’s entrepreneurial profile and intention. International Journal of Gender and Entrepreneurship, 10(4), 361-380. https://doi.org/10.1108/IJGE-04-2018-0032

Kristiansen, S. (2004). Entrepreneurial Intention Among Indonesian and Norwegian Students. In Journal of Enterprising Culture, 12(1). https://doi.org/10.1142/S021849580400004X

Krueger, N. F., Reilly, M. D., \& Carsrud, A. L. (2000). Competing models of entrepreneurial intentions. Journal of Business Venturing, 15(5), 411-432. https://doi.org/10.1016/S0883-9026(98)00033-0

Kuratko, D. F., \& Morris, M. H. (2018). Examining the future trajectory of entrepreneurship. Journal of Small Business Management, 56(1), 11-23. https://doi.org/10.1111/jsbm.12364

Laguía González, A., Jaén, I., Topa, G., \& Moriano, J. (2019). University environment and entrepreneurial intention: the mediating role of the components of the theory of planned behaviour. Revista de Psicologia Social, 34(1), 137167. https://doi.org/10.1080/02134748.2018.1542789

Lefever, S., Dal, M., \& Matthíasdóttir, Á. (2007). Online data collection in academic research: Advantages and limitations. British Journal of Educational Technology, 38(4), 574-582. https://doi.org/10.1111/j.14678535.2006.00638.x

Liguori, E. W., Bendickson, J. S., \& McDowell, W. C. (2018). Revisiting entrepreneurial intentions: A social cognitive career theory approach. International Entrepreneurship and Management Journal, 14(1), 67-78. https://doi.org/10.1007/s11365-017-0462-7

Liñán, F. (2004). Intention-based models of entrepreneurship education. Piccolla Impresa/Small Business, 3(1), 11-35. Retrieved from Based_Models_of_Entrepreneurship_Education https://www.researchgate.net/publication/235937886_Intention-

Lucas, W. A., \& Cooper, S. Y. (2004). Enhancing self-efficacy to enable entrepreneurship: The case of CMI's Connections. http://dx.doi.org/10.2139/ssrn.568383

Lüthje, C., \& Franke, N. (2003). The "making” of an entrepreneur: Testing a model of entrepreneurial intent among engineering students at MIT. REDD Management, 33(2), 135-147. https://doi.org/10.1111/1467-9310.00288

Maresch, D., Harms, R., Kailer, N., \& Wimmer-Wurm, B. (2016). The impact of entrepreneurship education on the entrepreneurial intention of students in science and engineering versus business studies university programs. Technological Forecasting and Social Change, 104, 172-179. https://doi.org/10.1016/j.techfore.2015.11.006

Markman, G. D., \& Baron, R. A. (2003). Person-entrepreneurship fit: Why some people are more successful as entrepreneurs than others. Human Resource Management Review, 13(2), 281-301. https://doi.org/10.1016/S1053-4822(03)00018-4

Maroufkhani, P., Wagner, R., \& Wan Ismail, W. K. (2018). Entrepreneurial ecosystems: a systematic review. Journal of Enterprising Communities, 12(4), 545-564. https://doi.org/10.1108/JEC-03-2017-0025

Mason, B. C., \& Brown, R. (2014). Entrepreneurial ecosystems and growth oriented entrepreneurship. Final Report to OECD, 30(1), 77-102. Retrieved from https://www.oecd.org/cfe/leed/Entrepreneurial-ecosystems.pdf

Miller, D. J., \& Acs, Z. J. (2017). The campus as entrepreneurial ecosystem: The University of Chicago. Small Business Economics, 49(1), 75-95. https://doi.org/10.1007/s11187-017-9868-4

Moore, J. F. (1993). Predators and prey: A new ecology of competition. Harvard Business Review, 71(3), 75-86. 
Retrieved from https://www.researchgate.net/publication/13172133

Moraes, G. H. S. M. de, Fischer, B. B., Campos, M. L., \& Schaeffer, P. R. (2020). University Ecosystems and the Commitment of Faculty Members to Support Entrepreneurial Activity. Brazilian Administration Review, 17(2). https://doi.org/10.1590/1807-7692bar2020190013

Moraes, G. H. S. M. de, Iizuka, E. S., \& Pedro, M. (2018). Effects of Entrepreneurial Characteristics and University Environment on Entrepreneurial Intention. Revista de Administração Contemporânea, 22(2), 226-248. https://doi.org/10.1590/1982-7849rac2018170133

Morris, M. H., Kuratko, D. F., \& Cornwall, J. R. (2013). Entrepreneurship Programs and the Modern University. Northampton, MA: Edward Elgar Publishing.

Morris, M. H., Shirokova, G., \& Tsukanova, T. (2017). Student entrepreneurship and the university ecosystem: A multi-country empirical exploration. European Journal of International Management, 11(1), 65-85. https://doi.org/10.1504/EJIM.2017.081251

Morris, M. H., Webb, J. W., Fu, J., \& Singhal, S. (2013). A competency-based perspective on entrepreneurship education: Conceptual and empirical insights. Journal of Small Business Management, 51(3), 352-369. https://doi.org/10.1111/jsbm.12023

Muscio, A., \& Ramaciotti, L. (2019). How does academia influence Ph.D. entrepreneurship? New insights on the entrepreneurial university. Technovation, 82-83, 16-24. https://doi.org/10.1016/j.technovation.2019.02.003

Mustafa, M. J., Hernandez, E., Mahon, C., \& Chee, L. K. (2016). Entrepreneurial intentions of university students in an emerging economy: The influence of university support and proactive personality on students' entrepreneurial intention. Journal of Entrepreneurship in Emerging Economies, 8(2), 162-179. https://doi.org/10.1108/JEEE-10-2015-0058

Neumeyer, X., Santos, S. C., \& Morris, M. H. (2019). Who is left out: Exploring social boundaries in entrepreneurial ecosystems. Journal of Technology Transfer, 44(2), 462-484. https://doi.org/10.1007/s10961-018-9694-0

Ngoc Khuong, M., \& Huu An, N. (2015). The factors affecting entrepreneurial intention of the students of Vietnam National University - A mediation analysis of perception toward entrepreneurship. Journal of Economics, Business and Management, 4(2), 104-111. https://doi.org/10.7763/joebm.2016.v4.375

Peterman, N. E., \& Kennedy, J. (2003). Enterprise education: Influencing students' perceptions of entrepreneurship. Entrepreneurship Theory and Practice, 28(2), 129-144. https://doi.org/10.1046\%2Fj.1540-6520.2003.00035.x

Piperopoulos, P., \& Dimov, D. (2015). Burst bubbles or build steam? Entrepreneurship education, entrepreneurial self-efficacy, and entrepreneurial intentions. Journal of Small Business Management, 53(4), 970-985. https://doi.org/10.1111/jsbm.12116

Qian, H., Acs, Z. J., \& Stough, R. R. (2013). Regional systems of entrepreneurship: The nexus of human capital, knowledge and new firm formation. Journal of Economic Geography, 13(4), 559-587. https://doi.org/10.1093/jeg/lbs009

Ratang, W., Blesia, J. U., Goldstein, B. L., Ick, M., \& Hutajulu, H. (2016). Using the action research process to design entrepreneurship education at Cenderawasih University. Procedia - Social and Behavioral Sciences, 228, 462469. https://doi.org/10.1016/j.sbspro.2016.07.071

Rideout, E. C., \& Gray, D. O. (2013). Does entrepreneurship education really work? A review and methodological critique of the empirical literature on the effects of university-based entrepreneurship education. Journal of Small Business Management, 51(3), 329-351. https://doi.org/10.1111/jsbm.12021

Ringle, C. M., \& Becker, J.-M. (2015). SmartPLS 3. www.smartpls.com

Robinson, S., \& Shumar, W. (2014). Ethnographic evaluation of entrepreneurship education in higher education: A methodological conceptualization. International Journal of Management Education, 12, 422-432.

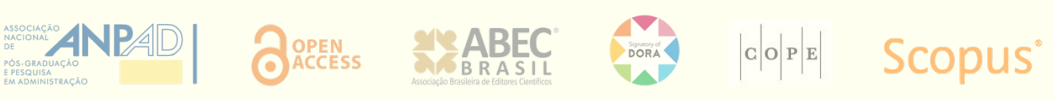


https://doi.org/10.1016/j.ijme.2014.06.001

Rosique-Blasco, M., Madrid-Guijarro, A., \& García-Pérez-de-Lema, D. (2018). The effects of personal abilities and self-efficacy on entrepreneurial intentions. International Entrepreneurship and Management Journal, 14(4), 10251052. https://doi.org/10.1007/s11365-017-0469-0

Rothaermel, F. T., Agung, S. D., \& Jiang, L. (2007). University entrepreneurship: A taxonomy of the literature. Industrial and Corporate Change, 16(4), 691-791. https://doi.org/10.1093/icc/dtm023

Saeed, S., Yousafzai, S. Y., Yani-De-Soriano, M., \& Muffatto, M. (2015). The role of perceived university support in the formation of students' entrepreneurial intention. Journal of Small Business Management, 53(4), 1127-1145. https://doi.org/10.1111/jsbm.12090

Sarstedt, M., Ringle, C. M., Cheah, J. H., Ting, H., Moisescu, O. I., \& Radomir, L. (2019). Structural model robustness checks in PLS-SEM. Tourism Economics. 26(4). https://doi.org/10.1177/1354816618823921

Schaeffer, P. R., Fischer, B., \& Queiroz, S. (2018). Beyond education: The role of research universities in innovation ecosystems. Foresight and STI Governance, 12(2), 50-61. https://doi.org/10.17323/2500-2597.2018.2.50.61

Schmidt, S., \& Bohnenberger, M. C. (2009). Perfil empreendedor e desempenho organizacional. Revista de Administração Contemporânea, 13(3), 450-467. https://doi.org/10.1590/S1415-65552009000300007

Shahab, Y., Chengang, Y., Arbizu, A. D., \& Haider, M. J. (2019). Entrepreneurial self-efficacy and intention: do entrepreneurial creativity and education matter? International Journal of Entrepreneurial Behaviour and Research, 25(2), 259-280. https://doi.org/10.1108/IJEBR-12-2017-0522

Shane, S., \& Venkataraman, S. (2000). The promise of entrepreneurship as a field of research. Management Review. 25(1). https://doi.org/10.5465/amr.2000.2791611

Shirokova, G., Osiyevskyy, O., \& Bogatyreva, K. (2016). Exploring the intention-behavior link in student entrepreneurship: Moderating effects of individual and environmental characteristics. European Management Journal, 34(4), 386-399. https://doi.org/10.1016/j.emj.2015.12.007

Souitaris, V., Zerbinati, S., \& Al-Laham, A. (2007). Do entrepreneurship programmes raise entrepreneurial intention of science and engineering students? The effect of learning, inspiration and resources. Journal of Business Venturing, 22(4), 566-591. https://doi.org/10.1016/j.jbusvent.2006.05.002

Stam, E., \& Spigel, B. (2016). Entrepreneurial Ecosystems. USE Discussion Paper Series, 16(13), 1-15. http://www.uu.nl/organisatie/utrecht-university-school-of-economics-

Sutter, C., Bruton, G. D., \& Chen, J. (2019). Entrepreneurship as a solution to extreme poverty: A review and future research directions. Journal of Business Venturing, 34(1), 197-214. https://doi.org/10.1016/j.jbusvent.2018.06.003

Testa, S., \& Frascheri, S. (2015). Learning by failing: What we can learn from un-successful entrepreneurship education. International Journal of Management Education, 13(1), 11-22. https://doi.org/10.1016/j.ijme.2014.11.001

Thompson, E. R. (2009). Individual entrepreneurial intention: Construct clarification and development of an internationally reliable metric. Enterpreneurship Theory and Practice, 33, 669-694. https://doi.org/10.1111/j.1540$6520.2009 .00321 . x$

Thursby, M. C., Fuller, A. W., \& Thursby, J. (2009). an integrated approach to educating professionals for careers in innovation. Academy of Management Learning $\mathcal{E}$ Education, 8(3), 389-405. https://doi.org/10.5465/amle.8.3.zqr389

Tiago, T., Faria, S., Couto, J. P., \& Tiago, F. (2015). Fostering innovation by promoting entrepreneurship: From education to intention. Procedia - Social and Behavioral Sciences, 175, 154-161. https://doi.org/10.1016/j.sbspro.2015.01.1186

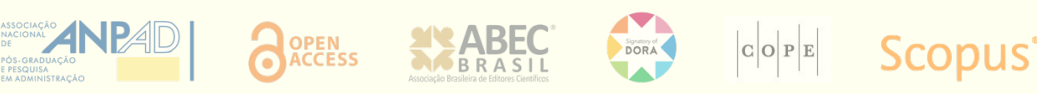


Trivedi, R. (2016). Does university play significant role in shaping entrepreneurial intention? A cross-country comparative analysis. Journal of Small Business and Enterprise Development, 23(3), 790-811. https://doi.org/10.1108/JSBED-10-2015-0149

Tsujimoto, M., Kajikawa, Y., Tomita, J., \& Matsumoto, Y. (2018). A review of the ecosystem concept - Towards coherent ecosystem design. Technological Forecasting and Social Change, 136, 49-58. https://doi.org/10.1016/j.techfore.2017.06.032

Turker, D., \& Selcuk, S. S. (2009). Which factors affect entrepreneurial intention of university students? Journal of European Industrial Training, 33(2), 142-159. https://doi.org/10.1108/03090590910939049

Vodă, A., \& Florea, N. (2019). Impact of personality traits and entrepreneurship education on entrepreneurial intentions of business and engineering students. Sustainability, 11(4), 1192. https://doi.org/10.3390/su11041192

von Graevenitz, G., Harhoff, D., \& Weber, R. (2010). The effects of entrepreneurship education. Journal of Economic Behavior and Organization, 76(1), 90-112. https://doi.org/10.1016/j.jebo.2010.02.015

Wegner, D., Thomas, E., Teixeira, E. K., \& Maehler, A. E. (2019). University entrepreneurial push strategy and students' entrepreneurial intention. International Journal of Entrepreneurial Behaviour and Research, 26(2), 307-325. https://doi.org/10.1108/IJEBR-10-2018-0648

World Economic Forum, Foster, G., Shimizu Project Leaders, C., Ciesinski, S., Davila, A., Zahoor Hassan, S., Jia, N., Plunkett, S., Pinelli, M., Cunningham, J., Hiscock-Croft, R., McLenithan, M., Rottenberg, L., Morris, R., \& World Economic Forum. (2013). Entrepreneurial Ecosystems Around the Globe and Company Growth Dynamics. http://www3.weforum.org/docs/WEF_EntrepreneurialEcosystems_Report_2013.pdf

Wurth, B., Stam, E., Spigel. (2021). Toward and Entrepreneurial Ecosystem Research Program. Entrepreneurship Theory and Practice. In press. https://doi.org/10.1177/1042258721998948

Zhao, H., Hills, G. E., \& Seibert, S. E. (2005). The mediating role of self-efficacy in the development of entrepreneurial intentions. Journal of Applied Psychology, 90(6), 1265-1272. https://doi.org/10.1037/00219010.90.6.1265 


\section{Authors' contributions}

$\mathbf{1}^{\text {st }}$ author: conceptualization (equal), data curation (equal), formal analysis (equal), investigation (equal), methodology (equal), validation (equal), writing-original draft (equal), writing-review \& editing (equal).

$2^{\text {nd }}$ author: conceptualization (equal), formal analysis (equal), investigation (equal), methodology (equal), supervision (lead), validation (equal).

$3^{\text {rd }}$ author: data curation (equal), writing-original draft (equal), writing-review $\&$ editing (equal).

\section{Authors}

\section{Matheus Leite Campos*}

Universidade Estadual de Campinas, Instituto de Geociências, InSySPo.

Rua Carlos Gomes, n. 250, Cidade Universitária, 13083-855, Campinas, SP, Brazil

matheusleite_98@hotmail.com

(iD) https://orcid.org/0000-0001-6943-4948

\section{Gustavo Hermínio Salati Marcondes de Moraes}

Universidade Estadual de Campinas, Faculdade de Ciências Aplicadas

Rua Pedro Zaccaria, n. 1300, 13484-350, Limeira, SP, Brazil

salati@unicamp.br

(iD) https://orcid.org/0000-0001-5238-0314

\section{Ana Carolina Spatti}

Universidade Estadual de Campinas, Instituto de Geociências

Rua Carlos Gomes, n. 250, Cidade Universitária, 13083-855, Campinas, SP, Brazil

carolspatti@hotmail.com

iD https://orcid.org/0000-0001-8839-8276

* Corresponding author

Peer review is responsible for acknowledging an article's potential contribution to the frontiers of scholarly knowledge on business or public administration. The authors are the ultimate responsible for the consistency of the theoretical references, the accurate report of empirical data, the personal perspectives, and the use of copyrighted material.

This content was evaluated using the double-blind peer review process. The disclosure of the reviewers' information on the first page is made only after concluding the evaluation process, and with the voluntary consent of the respective reviewers. 
